\title{
HOHEPA Wi NEERA: NATIVE TITLE AND THE PRIVY COUNCIL CHALLENGE
}

\author{
John William Tate*
}

The case of Hohepa Wi Neera illustrates an unprecedented clash of judicial approaches to native title claims. On the one hand, the New Zealand Court of Appeal was determined to continue the line of reasoning most notably enshrined in Wi Parata v Bishop of Wellington. On the other hand, the Privy Council, in Nireaha Tamaki v Baker had partially overturned Wi Parata by insisting that native title fell within the jurisdiction of the courts, at least when prerogative powers were not involved. The author argues that in Hohepa Wi Neera, the Court of Appeal quite deliberately tried to avoid the implications of the Privy Council's decision. In doing so, it exhibited a marked "colonial consciousness" which it was prepared to defend even to the extent of open breach with the Privy Council. The 1912 case of Tamihana Korokai v Solicitor-General, however, showed the extent to which the Court of Appeal was capable of shedding that "colonial consciousness" and embracing the earlier Privy Council ruling. The author demonstrates that this apparent irony sheds light on our understanding of the earlier cases.

The history of the New Zealand judiciary's response to native title claims in the wake of the Supreme Court's decision in Wi Parata v Bishop of Wellington ${ }^{1}$ in 1877 is of particular interest. This is because this response eventually brought the New Zealand Court of Appeal into open breach with the Privy Council in 1903. ${ }^{2}$ This breach was the product of a clear divergence between the Privy Council and the New Zealand Courts in terms of their willingness to recognise native title claims against the Crown. ${ }^{3}$ The New Zealand Court of Appeal's formal protest against the Privy Council in

* Lecturer in Politics, School of Policy, University of Newcastle, Australia. The author would like to thank the following library personnel for their assistance in the research process associated with this paper: Ann Stokes, Ruth Talbot-Stokes, Leone Clough, and Glen Burnett, Auchmuty Library, University of Newcastle, Australia; Margaret Greville, Law Librarian, University of Canterbury, Christchurch, New Zealand.

1 Wi Parata $v$ Bishop of Wellington (1878) 2 NZ Jur (NS) 72 (SC).

2 For the sake of brevity, throughout this paper the term "Privy Council" has been used to refer to the Judicial Committee of the Privy Council.

3 This breach manifested itself in a formal protest by the Court of Appeal against the Privy Council in 1903. The ostensible reason for the protest was the injudicious language which the Court of Appeal believed the Privy Council had used in Wallis v Solicitor General for New Zealand [1903] AC 173 to describe obiter 
1903, which confirmed this breach, and which is "the only recorded instance of a New Zealand Court's publicly avowing its disapproval of a superior tribunal", ${ }_{4}^{4}$ made clear that the New Zealand judges perceived the Privy Council's position on native title to be a definite threat to the stability and security of colonial land settlement in New Zealand. ${ }^{5}$

It is in this context that the New Zealand Court of Appeal's judgment in Hohepa Wi Neera $v$ Bishop of Wellington ${ }^{6}$ needs to be understood. This was the first native title case that the New Zealand Court of Appeal had adjudicated on in full knowledge of the Privy Council's recent departure from New Zealand precedent in this area - in particular, its move against Prendergast CJ's judgment in Wi Parata $v$ Bishop of Wellington, which had formed the dominant New Zealand precedent on native title for the past twenty-five years. ${ }^{7}$ Indeed, the New Zealand Courts had shown

dicta which the Court of Appeal had offered in a previous judgment, Solicitor-General v Bishop of Wellington [1901] 19 NZLR 665, which the Privy Council was overturning on appeal (see "Wallis and Others v Solicitor General, Protest of Bench and Bar, 25 April 1903", [1840-1932] NZPCC Appendix, 730, 730 Stout CJ; 747, 755-56 Williams J; 757 Edwards J). In particular, they objected to the implication, advanced by the Privy Council, that the point of view expressed by the Court of Appeal, in its obiter dicta, showed an undue subservience to the Executive (see "Wallis and Others $v$ Solicitor General, Protest of Bench and Bar, 25 April 1903", 755-56 Williams J; 757 Edwards J). However it is evident that, despite these protestations, the underlying issue of contention animating the protest was the extent to which the Privy Council's judgment in Wallis $v$ Solicitor-General, (along with its previous judgment in Nireaha Tamaki v Baker (1900-01) [1840-1932] NZPCC 371) broke from the precedent of Wi Parata on native title issues. All of the judges in the protest criticised the Privy Council's judgment in Wallis $v$ Solicitor-General in these substantive terms (see "Wallis and Others $v$ Solicitor General, Protest of Bench and Bar, 25 April 1903", above n 3, 732-34, 742-43 Stout CJ; 747-48, 749-50, 754-55 Williams J; 757 Edwards J). Indeed, all went as far as to accuse the Privy Council of ignorance of New Zealand law on these and other matters (see "Wallis and Others $v$ Solicitor General, Protest of Bench and Bar, 25 April 1903", 732, 737, 743, 745, 746 Stout CJ; 756 Williams J; 758-59 Edwards J).

4 Sir Robin Cooke "The Nineteenth Century Chief Justices" in Robin Cooke (ed) Portrait of a Profession. The Centennial Book of the New Zealand Law Society (AH and AW Reed, Wellington, 1969) 46.

5 Hence in the context of his protest, Chief Justice Stout said that if the dicta of the Privy Council in one of their native title cases were given effect to, "... no land title in the Colony would be safe." ("Wallis and Others v Solicitor General, Protest of Bench and Bar, 25 April 1903", above n 3, 746 Stout CJ). Similarly, Justice Edwards stated: "It would be easy by reference to numerous decisions of the Court of Appeal and of the Supreme Court of this Colony, and to statutes which, passed after such decisions, recognising their validity, have virtually confirmed them, to show still further that the interpretation which their Lordships have put upon the laws relating to Native lands in this Colony is subversive of the law which has prevailed from its foundation; and that if that interpretation were acted upon, and carried to its legitimate conclusion in future cases, the titles to real estates in this Colony would be thrown into irretrievable doubt and confusion." ("Wallis and Others v Solicitor General, Protest of Bench and Bar, 25 April 1903", above n 3, 757, Edwards J. Emphasis added).

Hohepa Wi Neera $v$ Bishop of Wellington (1902) 21 NZLR 655 (CA).

7 The Privy Council had departed from New Zealand's Wi Parata precedent in Nireaha Tamaki v Baker, above $\mathrm{n} 3$. Two years later it would do so again in Wallis $v$ Solicitor-General, above n 3. Although the Court of Appeal's judgment in Solicitor-General v Bishop of Wellington, above n 3 had been delivered after the 
a tenacious commitment to Wi Parata, not least its principle that the Crown is the "sole arbiter of its own justice" on native title matters, and so is capable of excluding the jurisdiction of the Courts. ${ }^{8}$ Indeed, one Court of Appeal judge, delivering the judgment of the Court some seventeen years after Wi Parata, stated that the "security of all titles in the country depends on the maintenance of this principle." 9

Consequently, Hohepa Wi Neera provides an interesting focus on how the Court of Appeal managed to steer its judgment between the scylla of its continued commitment to Wi Parata, and the charybdis of a recent decision by a superior court which moved against it. Indeed, as we shall see, the reasoning of the Court of Appeal in Hohepa Wi Neera provides evidence that it deliberately tried to evade the full implications of the Privy Council's recent decision on native title, and the threat which it posed to the Wi Parata precedent. It is even possible to explain the contours of the judgments in Hohepa Wi Neera precisely in terms of such a strategy. Consequently, far from the judges in Hohepa Wi Neera taking "scant stock" of the recent Privy Council ruling on native title, as Paul McHugh suggests, their judicial reasoning was defined and structured by their response to that very authority. ${ }^{10}$

Privy Council's judgment in Nireaha Tamaki v Baker, nevertheless the Privy Council judgment had not yet reached New Zealand before the Court of Appeal brought down its ruling in Solicitor-General v Bishop of Wellington (See "Wallis and Others v Solicitor General Protest of Bench and Bar, 25 April 1903", above n 3, 749 Williams J). Therefore the Hohepa Wi Neera judgment was the first native title ruling delivered by the Court of Appeal in full knowledge of the recent Privy Council departure from the Wi Parata precedent.

On Wi Parata v Bishop of Wellington as the authoritative New Zealand precedent on native title, at the time of the Hohepa Wi Neera judgment, see Nireaha Tamaki v Baker (1894) 12 NZLR 483, 488 Richmond J; Solicitor-General $v$ Bishop of Wellington, above n 3, 685-86 Williams J. Yet although the Wi Parata precedent was upheld by the main line of New Zealand judicial authority until the early years of the twentieth century, there were some minor exceptions. On these, see John William Tate, "Pre-Wi Parata: Early Native Title Cases in New Zealand" (2003) 11 Waikato LR 112.

8 Prendergast CJ articulated this principle as follows: "... in the case of primitive barbarians [among whom he clearly included the Maori tribes] the supreme executive Government must acquit itself, as best it may, of its obligations to respect native proprietary rights, and of necessity must be the sole arbiter of its own justice. Its acts in this particular cannot be examined or called in question by any tribunal, because there exist no known principles whereon a regular adjudication can be based." (Wi Parata v Bishop of Wellington, above n 1, 78 Prendergast CJ).

9 See Nireaha Tamaki v Baker, above n 7, 488 (CA) Richmond J.

10 See Paul McHugh, The Maori Magna Carta. New Zealand Law and the Treaty of Waitangi (Oxford University Press, Auckland, 1991) 119 [The Maori Magna Carta]. My thanks to the anonymous referee for the Victoria University of Wellington Law Review who brought this particular statement by McHugh to my attention. This paper also disagrees with the conclusion of Richard Boast and Andrew Erueti that, in the wake of the Privy Council ruling on native title in Nireaha Tamaki v Baker, which was the first Privy Council judgment to explicitly depart from Wi Parata, "[s]uch case law as there has been since 1901 has accepted the Privy Council's views rather than those of Prendergast CJ." (Richard Boast and Andrew Erueti, "Maori Customary Law and Land Tenure", in Richard Boast and others, Maori Land Law (Butterworths, 
The Court of Appeal's Hohepa Wi Neera judgment is therefore a very interesting focus on the workings of senior elements of the New Zealand judiciary at a time when they saw the New Zealand settlement of native title, as enshrined in Wi Parata, under significant threat from an imperial Court. It is the argument of this paper that the response of the New Zealand Court of Appeal to this threat indicated the presence of a "colonial consciousness" on their part, where their primary concern was to evade the Privy Council ruling and defend the legal settlement on native title which they saw as most conducive to settler interests, even at the expense of an open breach with the Privy Council.

\section{HOHEPA WI NEERA IN CONTEXT}

Hohepa Wi Neera $v$ Bishop of Wellington was a native title case concerning the same land, under the same grant, that the Court had adjudicated on the previous year in Solicitor-General v Bishop of Wellington. ${ }^{11}$ However unlike that previous case, it was adjudicated upon by the Court of Appeal in full knowledge of the Privy Council's recent ruling on native title in Nireaha Tamaki v Baker (1900-01). Although the Privy Council had delivered that judgment prior to the Court of Appeal ruling in Solicitor-General v Bishop of Wellington (1901), nevertheless the decision had not reached the Court of Appeal in time for it to influence their decision in that case. ${ }^{12}$ Hohepa Wi Neera $v$ Bishop of Wellington was therefore the first New Zealand case to adjudicate on native title in full knowledge of the Privy Council's decision.

But why is this significant? The answer lies in the extent to which the Privy Council's decision in Nireaha Tamaki $v$ Baker broke from established New Zealand precedent on native title and thereby redefined the judicial landscape in relation to it. As mentioned above, the reigning New Zealand precedent on native title up to that time was the New Zealand Supreme Court judgment of Wi Parata v Bishop of Wellington (1878). In that case, Prendergast CJ had resolved the native title issue in the interests of the Crown and settler society by insisting that native title matters involving the Crown were entirely a matter for the prerogative powers of the Crown, and were therefore outside the jurisdiction of the municipal courts. ${ }^{13}$ Prendergast CJ held that a mere declaration by the

Wellington, 1999) 16). On the contrary, Hohepa Wi Neera provides a clear instance of the Court of Appeal, one year after the Privy Council's ruling in Nireaha Tamaki v Baker, attempting to circumvent that ruling in order to maintain the authority of Prendergast CJ's judgment.

11 Solicitor-General v Bishop of Wellington, above $\mathrm{n} 3$. Both in turn were based on the same land and grant which arose for judgment in the Wi Parata case. (See Hohepa Wi Neera v Bishop of Wellington, above $\mathrm{n} 6$, 656 )

12 As Williams J put it: "The case of Nireaha Tamaki v Baker was decided by their Lordships shortly before our decision in [Solicitor-General v Bishop of Wellington, above n 3] but the judgment had not then reached the Colony." ("Wallis and Other v Solicitor-General, Protest of Bench and Bar, 25 April 1903", above n 3 , 749 Williams J).

13 Prendergast CJ identified native title matters with the prerogative powers of the Crown by insisting that Crown responsibilities regarding native title were akin to treaty obligations, and therefore any actions of the Crown arising from these responsibilities were acts of state, and for that reason, outside the jurisdiction of 
Crown that native title was extinguished on any particular piece of land was sufficient indication of the exercise of that prerogative and therefore conclusive on the Courts. ${ }^{14}$ The result, according to Prendergast CJ, was that no native title claim could prevail against the Crown, unless the Crown itself wished the claim to succeed, thereby ensuring that all Crown titles were safe from unwanted legal challenge in this respect. ${ }^{15}$

Such a ruling was clearly in the interests of the Crown and the settlers who held Crown titles. Prendergast CJ had asserted that the Crown could unilaterally conclude any native title claim, simply by declaring that the native title had indeed been lawfully extinguished, and Maori had no recourse to judicial appeal against such a declaration because, native title matters involving the Crown falling within the latter's prerogative powers, the Crown was the "sole arbiter of its own justice". ${ }^{16}$ One could not imagine a precedent more conducive to providing stability and security to settler interests in the colonizing process, at the expense of those Maori tribes whose land was now subject to that colonization.

the courts. As Prendergast CJ put it, the Crown's duty of protecting the Maori tribes from "... any infringement of their right of occupancy ... although not to be regarded as properly a treaty obligation, is yet in the nature of a treaty obligation. It is one, therefore, with the discharge of which no other power in the State can pretend to interfere. The exercise of the right and the discharge of the correlative duty, constitute an extraordinary branch of the prerogative, wherein the sovereign represents the entire body-politic, and not, as in the case of ordinary prerogative, merely the Supreme Executive power." (Wi Parata v Bishop of Wellington, above $\mathrm{n}$ 1, 78-79). Prendergast CJ therefore concludes: "Transactions with the natives for the cession of their title to the Crown are thus to be regarded as acts of State, and therefore are not examinable by any Court ... Especially it cannot be questioned, but must be assumed, that the sovereign power has properly discharged its obligations to respect, and cause to be respected, all native proprietary rights." ( $W i$ Parata v Bishop of Wellington, above n 1, 79). Paul McHugh has criticised Prendergast CJ's conclusion that the Crown's dealings with Maori over native title were "acts of State", on the following grounds: "By 1877 the Maori's status as British subjects had been long fixed - how then could an 'act of state' be made by the Crown against its own subjects?" (Paul McHugh, "Aboriginal Title in New Zealand Courts" (1894) 2 Canterbury LR 247 ["Aboriginal Title in New Zealand Courts"]. McHugh points out that a long line of judicial authority had established "... that as between the sovereign and a subject there can be no act of State on British territory...." ("Aboriginal Title in New Zealand Courts", 247 n 55). See also, The Maori Magna Carta, above n 10, 114 .

14 As Prendergast CJ put it: "In this country the issue of a Crown grant undoubtedly implies a declaration by the Crown that the native title over the land which it comprises has been extinguished. For the reason we have given, this implied fact is one not to be questioned in any Court of Justice, unless indeed the Crown should itself desire to question it, and should call upon the Court to lend its aid in correcting some admitted mistake." (Wi Parata v Bishop of Wellington, above $\mathrm{n} 1$ 1, 78). Prendergast CJ also pointed to a general prerogative power of the Crown to declare native title extinguished, independent of Crown grant (see $\mathrm{Wi}$ Parata $v$ Bishop of Wellington, above n 1,80).

15 See Wi Parata $v$ Bishop of Wellington, above n 1, 78 Prendergast CJ.

16 See Wi Parata $v$ Bishop of Wellington, above n 1, 78 Prendergast CJ. 


\section{THE PRIVY COUNCIL DEPARTURE FROM WI PARATA}

It is in this context that the impact of the Privy Council's departure from the Wi Parata precedent in Nireaha Tamaki $v$ Baker must be understood. In departing from Wi Parata, the Privy Council was producing nothing less than a fundamental upheaval in the New Zealand legal landscape concerning issues of land settlement. The fact that, as we shall see below, the Privy Council's departure from Wi Parata was only partial, leaving some primary elements of the judgment intact, only heightens the significance of the New Zealand judicial response. Any suggestion that the Wi Parata precedent was in question, no matter how partial, was sufficient to arouse the concern of the New Zealand Bench, given the centrality of this precedent to land title and land settlement in New Zealand. ${ }^{17}$

In Nireaha Tamaki $v$ Baker, the Privy Council considered an appeal against a New Zealand Court of Appeal decision of the same name, decided in 1894. The 1894 case involved a claim by the plaintiff that land which the Crown had put up for sale belonged to him either under a Native Land Court order of 1871, or on the basis of native title. ${ }^{18}$ The Court of Appeal held that the former basis for title was void, and so the case proceeded on the assumption that the plaintiff was asserting a "pure Maori title" to the land. ${ }^{19}$ The two questions which therefore arose for adjudication in the 1894 case were: 20

(1) Can the interest of the Crown in the subject-matter of this suit be attacked by this proceeding?

(2) Has the Court jurisdiction to inquire whether, as a matter of fact, the land in dispute herein has been ceded by the Native owners to the Crown?

The Court of Appeal answered both questions in the negative, upholding the principle of $W i$ Parata that native title matters involving the Crown fell entirely within the Crown's prerogative powers, and therefore outside the jurisdiction of the Courts, so that the Crown was the sole determinant of justice in the matter. As Richmond J, delivering the judgment of the Court, put it: ${ }^{21}$

The plaintiff comes here ... on a pure Maori title, and the case is within the direct authority of Wi Parata

$v$ The Bishop of Wellington. ... We see no reason to doubt the soundness of that decision. ... According

to what is laid down in the case cited, the mere assertion of the claim of the Crown is in itself sufficient to oust the jurisdiction of this or any other Court in the colony. There can be no known rule of law by

17 See "Wallis and Others v Solicitor General, Protest of Bench and Bar, 25 April 1903", above n 3, 732-34, 742-43, 746 Stout CJ; 747-48, 749-50, 754-55 Williams J; 757 Edwards J.

18 See Nireaha Tamaki v Baker, above n 7, 487-488 (CA).

19 See Nireaha Tamaki v Baker, above n 7, 488 (CA) Richmond J.

20 Nireaha Tamaki v Baker, above n 7, 485 (CA).

21 Nireaha Tamaki v Baker, above n 7, 488 Richmond J (CA). 
which the validity of dealings in the name and under the authority of the Sovereign with the Native tribes of this country for the extinction of their territorial rights can be tested. Such transactions began with the settlement of these Islands; so that Native custom is inapplicable to them. The Crown is under a solemn engagement to observe strict justice in the matter, but of necessity it must be left to the conscience of the Crown to determine what is justice. The security of all titles in the country depends on the maintenance of this principle.

The plaintiff appealed to the Privy Council against this decision, and the same two questions arose for adjudication. The Privy Council reversed the decision of the Court of Appeal on the second question, finding that the Courts do have jurisdiction "... to inquire whether as a matter of fact the land in dispute has been ceded by the native owners to the Crown in accordance with law..."22 It did so on the basis of finding that the Native Rights Act 1865, was a clear statutory recognition of the legal existence of native title in New Zealand, and its justiciability in the Courts. ${ }^{23}$ However, the Privy Council reserved judgment on the first question, insisting that the issue of the Crown's prerogative powers, which according to Wi Parata barred any legal challenge on native title matters involving the Crown, did not arise in this case. ${ }^{24}$ Rather, as we shall see below, the Privy Council held that any authority exercised by the Crown officers in this case was exercised under statutory authority, rather than the prerogative, and so that authority was justiciable in the Courts. ${ }^{25}$

Consequently, the Privy Council's overturning of the Wi Parata precedent in Nireaha Tamaki v Baker was only partial. It insisted that native title fell within the jurisdiction of the Courts, but on a statutory basis - the Native Rights Act 1865. Yet it reserved judgment on whether native title would still fall within the jurisdiction of the Courts if the Crown's prerogative powers were involved - that is, the very principle which was central to Wi Parata. Further, the Privy Council actually affirmed the final ruling of Prendergast CJ regarding the facts of the case in Wi Parata, including the ruling that the existence of a Crown grant was sufficient declaration by the Crown that the native title had been lawfully extinguished. ${ }^{26}$ It simply disagreed with some of his wider obiter dicta on native title.

22 Nireaha Tamaki v Baker, above n 3, 385 (PC).

23 Nireaha Tamaki v Baker, above n 3, 382-83 (PC).

24 As Lord Davey put it, delivering the judgment of the Privy Council: "Their Lordships ... express no opinion on the question which was mooted in the course of the argument whether the Native title could be extinguished by the exercise of the prerogative, which does not arise in the present case." (Nireaha Tamaki $v$ Baker, above n 3, 385 (PC)).

25 See Nireaha Tamaki v Baker, above n 3, 380-81 (PC).

26 As Lord Davey stated: "In the case of Wi Parata $v$ The Bishop of Wellington, already referred to, the decision was that the Court has no jurisdiction by scire facias or other proceeding to annul a Crown grant for matter not appearing on the face of it, and it was held that the issue of a Crown grant implies a declaration by the Crown that the Native title has been extinguished ... But the dicta in the case go beyond what was necessary for the decision ... As applied to the case then before the Court however, their 
This disagreement was based in particular on Prendergast CJ's initial denial of the very existence of native title, embodied in Maori customary law. ${ }^{27}$ As Lord Davey put it: ${ }^{28}$

[I] t was said in the case of Wi Parata $v$ Bishop of Wellington, which was followed by the Court of Appeal in this case, that there is no customary law of the Maoris of which the Courts of law can take cognizance. Their Lordships think that this argument goes too far, and that it is rather late in the day for such an argument to be addressed to a New Zealand Court. It does not seem possible to get rid of the express words of ss 3 and 4 of the Native Rights Act, 1865, by saying (as the Chief Justice said in the case referred to) that 'a phrase in a statute cannot call what is non-existent into being'. It is the duty of the Courts to interpret the statute which plainly assumes the existence of a tenure of land under custom and usage which is either known to lawyers or discoverable by them by evidence... The legislation both of the Imperial Parliament and of the Colonial Legislature is consistent with this view of the construction and effect of the Native Rights Act, and one is rather at a loss to know what is meant by such expressions 'Native title', 'Native lands', 'owners', and 'proprietors', or the careful provision against sale of Crown lands until the Native title has been extinguished if there be no such title cognizable by the law and no title therefore to be extinguished.

However despite these criticisms of Prendergast CJ's judgment, we have seen that the Privy Council stopped short of challenging the central doctrine of the Wi Parata precedent - that native title matters involving the Crown were subject to the Crown's prerogative powers, and so outside the jurisdiction of the Courts. The Privy Council therefore overturned the 1894 decision of the Court of Appeal, and its defence of Wi Parata, by holding that in this particular case, the native title matters

Lordships see no reason to doubt the correctness of the conclusion arrived at by the learned Judges." (Nireaha Tamaki v Baker, above n 3, 383-84 (PC)).

27 Hence at one point in his Wi Parata judgment, Prendergast CJ went so far as to assert a terra nullius position that native title did not exist, on the grounds that there was no Maori customary law to sustain it. For instance, after referring to the New South Wales Act, 4 Vict 7, and the Land Claims Ordinance 1841, Prendergast states: "... these measures were avowedly framed upon the assumption that there existed amongst the natives no regular system of territorial rights nor any definite ideas of property in land ..." ( $\mathrm{Wi}$ Parata $v$ Bishop of Wellington, above $\mathrm{n} 1,77$ ). Later in his judgment he criticises the reference in the Native Rights Act 1865 to the "Ancient Custom and Usage of the Maori People", "... as if some such body of customary law did in reality exist. But a phrase in a statute cannot call what is non-existent into being. As we have shown, the proceedings of the British Government and the legislation of the colony have at all times been practically based on the contrary supposition, that no such body of law existed; and herein have been in entire accordance with good sense and indubitable facts." (Wi Parata v Bishop of Wellington, above $\mathrm{n} 1,79)$. Such a position was clearly at odds with Prendergast CJ's insistence elsewhere in his judgment that native title did indeed exist, but was subject to the prerogative powers of the Crown. Subsequent judicial authority upheld this latter position as the authoritative precedent on Wi Parata and tended to ignore the former terra nullius position (see Nireaha Tamaki v Baker, above $\mathrm{n} 7$ (CA); Solicitor-General v Bishop of Wellington, above $\mathrm{n} 3$; Tate, above $\mathrm{n}$ 7.)

28 Nireaha Tamaki v Baker, above n 3, 382-83 (PC). 
involving the Crown did fall within the Court's jurisdiction, but only on the assumption that the question of the Crown's prerogative over native title did not arise: ${ }^{29}$

Their Lordships are therefore of opinion that the order of the Court of Appeal should be reversed, and a declaration should be made in answer to the third and fourth issues of law as follows: That it not appearing that the estate and interest of the Crown in the subject-matter of this suit subject to such Native titles (if any) as have not been extinguished in accordance with law is being attacked by this proceeding, the Court has jurisdiction to inquire whether as a matter of fact the land in dispute has been ceded by the Native owners to the Crown in accordance with law..

\section{IMPACT ON WI PARATA}

Nevertheless, despite these qualifications, the Privy Council's judgment was a significant departure from the Wi Parata precedent. This was due to the identity of the respondent in the case. The respondent was a senior Crown official - the Commissioner of Crown Lands for the Wellington District. ${ }^{30}$ It was his authority to sell the lands in accordance with the Land Act, 1892, which was being challenged by the appellant in this case. The appellant insisted that part of the lands proposed for sale by the Land Commissioner were lands upon which the native title had not been extinguished. ${ }^{31}$ The Land Commissioner insisted, on the basis of Wi Parata, that because native title claims involving the Crown were a matter for the Crown's prerogative, the Courts had no jurisdiction to determine this claim, and the declaration of the Crown was conclusive on the matter. ${ }^{32}$ As we have seen, the New Zealand Court of Appeal had agreed with this latter position,

29 Nireaha Tamaki v Baker, above n 3, 385 (PC).

30 See Nireaha Tamaki v Baker, above n 7, 483 (CA). At one point, the defendants also included the AttorneyGeneral for New Zealand. In the facts of the case outlined in the 1894 judgment, the Court of Appeal stated: "The plaintiff took out a summons for leave to join the Attorney-General as a defendant, and, on the order being made for the argument of questions of law, it was agreed between the parties that, if the Court was of opinion that the Attorney-General was a necessary party, the questions should be dealt with as if he had been made a party, and had raised all the defences raised by the defendant." (Nireaha Tamaki v Baker, above n 7, 485 (CA)). The Court of Appeal held that the Attorney-General was a necessary party to the case, stating: "In our opinion, the Attorney-General is a necessary party to this suit, and, that being so, he is by consent to be considered as a defendant ..." (Nireaha Tamaki v Baker, above n 7, 487 (CA)). However the Privy Council rejected this ruling on appeal, stating: "The Court of Appeal thought that the AttorneyGeneral was a necessary party to the action, but it follows from what their Lordships have said as to the character of the action that in their opinion he was neither a necessary nor a proper party." (Nireaha Tamaki $v$ Baker, above n 3, 381 (PC)).

31 See Nireaha Tamaki v Baker, above n 7, 483 (CA).

32 As Council for the Defence stated for the Land Commissioner: "The Court has no jurisdiction to entertain the suit. The acts and proceedings of the Crown are conclusive that the Native title has been extinguished: Wi Parata $v$ Bishop of Wellington [above n 1]. The declaration gazetted under section 136 of 'The Land Act, 1892 ', is alone a sufficient exercise of the Crown's prerogative in this respect." (Nireaha Tamaki v Baker, above n 7, 486-87 (CA) Gully). 
and so had declined jurisdiction over the matter. ${ }^{33}$ Yet the Privy Council was able to arrive at the contrary conclusion, by ruling that the Commissioner of Crown Lands, although an official of the Crown, was exercising his authority under statutory powers, and not the Crown's prerogative powers. On this basis, the Privy Council argued, the issue of the Crown's prerogative powers did not arise, and so the case was justiciable before the Courts. As Lord Davey put it: ${ }^{34}$

Their Lordships think that the learned Judges have misapprehended the true object and scope of the action, and that the fallacy of their judgment is to treat the respondent as if he were the Crown or acting under the authority of the Crown for the purposes of this action. The object of the action is to restrain the respondent from infringing the appellant's rights by selling property on which he alleges an interest in assumed pursuance of a statutory authority the conditions of which (it is alleged) have not been complied with. The respondent's authority to sell on behalf of the Crown is derived solely from the statutes and is confined within the four corners of the statutes. The Governor in notifying that the lands were rural land open for sale was acting and stated himself to be acting in pursuance of s. 136 of the Land Act, 1892, and the respondent in his notice of sale purports to sell in terms of s. 137 of the same Act. If the land were not within the powers of those sections (as is alleged by the appellant), the respondent had no power to sell the lands, and his threat to do so was an unauthorized invasion of the appellant's alleged rights.

So the Privy Council ruled in favour of the appellant and his native title claims, and against the Commissioner of Crown Lands, solely in terms of the Commissioner's statutory powers, thereby reserving judgment on the extent to which the Crown still retained prerogative powers over native title. ${ }^{35}$ Yet this was of little comfort to the authorities in New Zealand, who quickly saw the full implications of the Privy Council judgment for the Wi Parata precedent. ${ }^{36}$ Most alarmingly, the

33 See Nireaha Tamaki v Baker, above n 7, 488 (CA) Richmond J.

34 Nireaha Tamaki v Baker, above n 3, 380-81 (PC).

35 As Lord Davey put it: "... there is no suggestion of the extinction of the appellant's title by the exercise of the prerogative outside the statutes if such a right still exists." (Nireaha Tamaki v Baker, above n 3, 381-82 $(\mathrm{PC}))$.

36 Indeed, according to Paul McHugh, the New Zealand Parliament passed the Land Titles Protection Act 1902 in response to this Privy Council decision (See The Maori Magna Carta, above n 10, 118). The long title to the Act described it as "An Act to protect the Land Titles of the Colony from Frivolous Attacks in certain Cases." (Land Titles Protection Act 1902, No 37, 2 Edw VII. Section 2(1) of the Act then proceeded to protect the Crown from any native title claims which the Crown itself did not wish to entertain: "In the case of Native land or land acquired from Natives, the validity of any order of the Native Land Court, Crown grant, or other instrument of title purporting to have been issued under the authority of law which has subsisted for not less than ten years prior to the passing of this Act shall not be called in question in any Court, or be the subject of any order of the Chief Judge of the Native Land Court ... unless with the consent of the Governor in Council first had and obtained; and in the absence of such consent this Act shall be an absolute bar to the initiation of any proceedings in any Court calling in question the validity of any such order, Crown grant or instrument of title, or the jurisdiction of the Native Land Court to make any such order, or the power of the Governor to make and issue any such Crown grant." Consequently, the Land 
ruling meant that Prendergast CJ's conclusion that the Crown was the "sole arbiter of its own justice" on native title issues no longer held. The actions of Crown officials, relating to the extinguishment of native title, could now be adjudicated upon by the Courts, so long as the Court found that the Crown officials were not exercising the prerogative powers of the Crown, but rather were acting under statutory authority. Whether they were acting under Crown or statutory authority was clearly an open question, given that the Court of Appeal had ruled in 1894 that the Land Commissioner was exercising the Crown's prerogative powers, and the Privy Council had ruled seven years later that he was not.

In other words, the central platform of the Wi Parata precedent, and of the land settlement process in New Zealand - that native title matters involving the Crown fell exclusively within the prerogative powers of the Crown and so outside the jurisdiction of the Courts - was looking extremely shaky. Despite the fact that the Privy Council had denied it was challenging those prerogative powers, in practical terms the outcome of their judgment was to establish a precedent that native title matters involving the Crown could be subject to the jurisdiction of the Courts in specified circumstances. ${ }^{37}$ The authority of the Wi Parata precedent to protect the land settlement process in New Zealand from native title challenge had therefore been broken. From a settler perspective therefore, the Privy Council's decision in Nireaha Tamaki v Baker had rendered the land settlement process in New Zealand subject to uncertainty and insecurity.

This was clearly recognised by the New Zealand Court of Appeal judges. For instance, two years later, in the Court of Appeal's protest against the Privy Council, Stout CJ stated that if the dicta of the Privy Council in Nireaha Tamaki v Baker (1901) were given effect to, "... no land title in the Colony would be safe." 38 Similarly, referring to the Privy Council's decision in Nireaha Tamaki v Baker (1900-01) and Wallis v Solicitor-General (1903), both of which departed from the Wi Parata precedent, Edwards J articulates a similar sentiment, stating that "... the interpretation which their Lordships have put upon the laws relating to Native lands in this Colony is subversive of the law which has prevailed from its foundation; and ... if that interpretation were acted upon, and

Titles Protection Act 1902, passed soon after the Privy Council's decision in Nireaha Tamakiv Baker, above n 3 (PC), was clearly a legislative attempt to defend the Crown's prerogative powers over native title, which were believed to have been attacked in that case, by giving them a statutory basis. It therefore sought to enshrine the Wi Parata precedent, which had hitherto protected the Crown from unwanted native title claims, in statutory law.

37 Indeed, the Privy Council even seemed to question whether this Crown prerogative power over native title was still in existence, suggesting that all conceivable instances of extinguishment of native title by the Crown would now be regulated by statute (see Nireaha Tamaki $v$ Baker, above n 3, 381-82 (PC)). Though again, they refrained from any definitive judgment on this question.

38 "Wallis and Others v Solicitor-General, Protest of Bench and Bar, 25 April 1903", above n 3, 746 Stout CJ. 
carried to its legitimate conclusion in future cases, the titles to real estates in this Colony would be thrown into irretrievable doubt and confusion." 39

\section{THE HOHEPA WI NEERA JUDGMENT}

So how did the Court of Appeal deal with this direct challenge to the Wi Parata precedent? The answer lay in their response to a native title case which arose the following year, Hohepa Wi Neera $v$ Bishop of Wellington (1902). In normal circumstances, this case would have fallen directly within the authority of Wi Parata and would have been decided in identical terms to that case. This is because the facts of the case were the same as Wi Parata, involving the same land and the same grant to the Bishop of Wellington. The Hohepa Wi Neera case therefore provided a clear confrontation between the established Wi Parata precedent and the new Privy Council ruling in Nireaha Tamaki v Baker. As we shall see, much of the Court of Appeal's reasoning in this case can be understood as a definite attempt to preserve central elements of the Wi Parata precendent from the impact of the Privy Council's recent decision. The case therefore provides a clear example of the extent to which the Court of Appeal was willing to go in evading a ruling of a superior Court in order to maintain a cherished New Zealand precedent on native title.

\section{A The Facts of the Case}

The facts of the Hohepa Wi Neera case were very similar to those arising in Wi Parata $v$ Bishop of Wellington and Solicitor-General v Bishop of Wellington. ${ }^{40}$ Indeed Williams J states: "It is difficult to distinguish the present case from the case of Wi Parata $v$ The Bishop of Wellington, which dealt with the same subject-matter." 41 While the judgment of the Court of Appeal in The Solicitor-General $v$ The Bishop of Wellington (1901) was being appealed in the Privy Council, a member of the Ngatitoa tribe, Hohepa Wi Neera, brought another action against the Bishop of Wellington and the Solicitor-General. He claimed that he was the successor to one of the native parties who had signed an 1848 letter ceding land to the Bishop of Wellington for the building of a college in the area of Porirua. ${ }^{42}$ In this action "... he sought to have it declared that the Crown grant [to the Bishop] was void, and, further, that the land had never been ceded by the Natives, that the Native title had never been extinguished, and that the land was still owned according to Native

39 "Wallis and Others v Solicitor-General, Protest of Bench and Bar, 25 April 1903", above n 3, 757 Edwards $\mathrm{J}$ (emphasis added).

40 See Hohepa Wi Neera v Bishop of Wellington, above n 6, 655, 656.

41 Hohepa Wi Neera $v$ Bishop of Wellington, above n 6, 671 Williams J.

42 Hohepa Wi Neera $v$ Bishop of Wellington, above n 6, 656. 
custom by the successors of those entitled in 1848."43 Argument of questions of law before trial were therefore removed to the Court of Appeal. ${ }^{44}$

\section{B Stout CJ and the Recognition of Native Title}

Chief Justice Stout began his judgment in Hohepa Wi Neera with an attempt to firmly establish the legal basis of native title within New Zealand law. He began by referring to chapter xii, section 9 of the Imperial Instructions of 1846 which, he says, allows land claims of aboriginal inhabitants to be admitted to prospective statutory land courts (as distinct from municipal courts) if "... the claimants or their progenitors or those from whom they derived title had actually had the occupation of the lands so claimed, and had been accustomed to use and enjoy the same either as places of abode, or for tillage, or for the growth of crops, or for the depasturing of cattle, or otherwise for the convenience and sustentation of life by means of labour expended thereon." $45 \mathrm{He}$ also points to the Native Rights Act of 1865 with its reference to "... titles to land held under Maori custom and usage ...". 46 The latter seems to amount to a clear admission, on the part of Stout CJ, of the statutory recognition of customary occupation and use of land as a legitimate basis for land title among the Maori population. In other words, in addition to the 1846 Instructions, it appears to be an effective recognition of native title, and to this extent, clearly departs from those elements of Prendergast CJ's judgment in Wi Parata which, at some points, had denied the very existence of such title. ${ }^{47}$

Stout CJ then points to the establishment of statutory procedures for the investigation of native title, beginning in 1862, and involving the establishment of a Native Land Court in 1865. He states: "There has since 1865 ever been a Native Land Court to investigate Native title; and the uniform rule has been, until such investigation was determined the Supreme Court did not recognise the title of any Native to sue for possession of land uninvestigated by the [Land] Court."48 While this moves in the direction of the Wi Parata principle that native title, in and of itself, lies outside the jurisdiction of the municipal courts, it is not a denial of the existence of native title. Indeed, it is precisely such title that the statutory Land Court was established to investigate.

Finally, Stout CJ points out that under the terms of the Instructions of $1846, " \ldots$ lands not claimed by or on behalf of the Maoris were deemed the demesne lands of the Crown." ${ }^{49}$ Again, this

43 Hohepa Wi Neera v Bishop of Wellington, above n 6, 655.

44 Hohepa Wi Neera v Bishop of Wellington, above n 6, 656.

45 Hohepa Wi Neera $v$ Bishop of Wellington, above n 6, 664-65, Stout CJ.

46 Hohepa Wi Neera v Bishop of Wellington, above n 6, 666 Stout CJ.

47 See Wi Parata v Bishop of Wellington, above n 1, 77; 79.

48 Hohepa Wi Neera v Bishop of Wellington, above n 6, 665 Stout CJ.

49 Hohepa Wi Neera v Bishop of Wellington, above n 6, 664 Stout CJ. See also Hohepa Wi Neera v Bishop of Wellington, above n 6, 663 Stout CJ. 
is an implicit recognition of native title, since in the absence of native title, all land would be demesne lands of the Crown, until ceded by grant to settlers. ${ }^{50}$

As we have seen, although at some points within the Wi Parata judgment, Prendergast CJ had articulated what seemed to be a terra nullius doctrine by denying the existence of native title altogether, at other points he fully affirmed the existence of native title but confined it within the prerogative powers of the Crown, thereby denying the municipal courts any jurisdiction to investigate native title in and of itself. ${ }^{51}$ It is this second aspect of the Wi Parata precedent which

50 This was the inevitable conclusion of the terra nullius doctrine, which applied in the absence of native title. This doctrine held that upon the acquisition of sovereignty over newly discovered territory, the Crown acquired all land as demesne lands of the Crown. This doctrine was asserted by the defence in the Mabo case. Justice Brennan articulated their position, for the sake of exposition, as follows: "On analysis, the defendant's argument is that, when the territory of a settled colony became part of the Crown's dominions, the law of England so far as applicable to colonial conditions became the law of the colony and, by that law, the Crown acquired the absolute beneficial ownership of all land in the territory so that the colony became the Crown's demesne and no right or interest in any land in the territory could thereafter be possessed by any other person unless granted by the Crown." (Mabo v Queensland [No. 2] (1992) 175 CLR 1, 26 Brennan J.).

51 Such inconsistencies were a marked feature of Prendergast CJ's Wi Parata judgment. At one point, Prendergast CJ seemed to deny the Courts any jurisdiction to investigate native title claims, in and of themselves, when he said: "On the one hand, it has always been certain that a Maori could bring trespass or ejectment in respect of land held by him under a Crown grant. On the other hand, it has been equally clear that the Court could not take cognizance of mere native rights to land." (Wi Parata v Bishop of Wellington, above n 1, 79. Emphasis added). However elsewhere in his judgment, Prendergast CJ seemed to imply that there were times when the municipal courts would have jurisdiction over native title claims, such as when the Crown actively supported that jurisdiction. As he put it: "In this country the issue of a Crown grant undoubtedly implies a declaration by the Crown that the native title over the land which it comprises has been extinguished. For the reason we have given, this implied fact is one not to be questioned in any Court of Justice, unless indeed the Crown should itself desire to question it, and should call upon the Court to lend its aid in correcting some admitted mistake." (Wi Parata v Bishop of Wellington, above n 1, 78. Emphasis added). Prendergast CJ's brother judge in the Wi Parata case, Richmond J, went even further and suggested that the municipal courts might have jurisdiction over native title in those cases where the Crown was not involved, thereby allowing the Court to refer the matter to the appropriate statutory body, the Native Land Court. As Richmond J put it: "The Native Rights Act, 1865, declares this Court shall take cognizance of Maori custom, but the Legislature requires us to send any question of Maori title to the Native Lands Court. It is as much as to say, it is a jurisdiction we are incapable of exercising ... If you can imagine such a thing as the rights of natives inter se, questions of that kind must go to the Native Lands Court ... [However] [i] $\mathrm{t}$ is quite plain that we have no power to refer to the Native Lands Court the question whether the native title has been effectually extinguished by her Majesty, and it would be a monstrous thing if we could be required to do it." (Wi Parata v Bishop of Wellington, above n 1, 75. Emphasis added). Consequently, if we ignore those points in the Wi Parata judgment where Prendergast CJ adopts a fully blown terra nullius position, we can see that the judgment actually gives rise to conflicting precedent concerning the extent to which the municipal courts have jurisdiction over native title matters, in and of themselves. At times Prendergast CJ implies that all native title matters are excluded from the jurisdiction of the Courts. At other times, both Prendergast CJ and Richmond J seem to exclude only those cases where the Crown is involved and where it does not support the matter appearing before the Courts. 
was upheld by subsequent New Zealand judicial decisions on native title. ${ }^{52}$ The question therefore arises of how far Stout CJ, and his brother judge, Williams $\mathrm{J}$, moved beyond this precedent in Hohepa Wi Neera.

\section{The Impact of Nireaha Tamaki v Baker}

As we have seen, the Privy Council's decision in Nireaha Tamaki $v$ Baker departed from the Wi Parata precedent by insisting that native title issues involving Maori and the executive government did fall within the jurisdiction of the municipal courts, to the extent that they fell within the scope of statutory authority, although it reserved judgment on issues of Crown prerogative. As discussed above, despite this qualification, the Privy Council decision was still understood in New Zealand as a threat to the Wi Parata precedent, because it meant that the Crown could now be subject to native title challenge in the Courts.

In Nireaha Tamaki, the Privy Council further departed from the Wi Parata precedent in their interpretation of the Native Rights Act 1865. In Wi Parata, Prendergast CJ had insisted that the legislature had not intended that the Crown be bound by the Native Rights Act 1865, because the Crown was not specifically mentioned in the Act. ${ }^{53}$ He therefore ruled that the Crown could not be ordered by the Supreme Court to appear before the statutory Native Land Court in order to have native title matters determined under the terms of the Act. ${ }^{54}$ Yet this was the very Act which the Privy Council relied on in Nireaha Tamaki to bind the Crown by holding that the Supreme Court could order that native title matters involving the Crown be referred for determination to that same statutory Court. As Lord Davey put it: ${ }^{55}$

By section 5 it is plainly contemplated that cases might arise in the Supreme Court in which the title or some interest in Native land is involved, and in that case provision is made for the investigation of such titles and the ascertainment of such interests being remitted to a Court specifically constituted for the purpose. The legislation both of the Imperial Parliament and of the Colonial Legislature is consistent with this view of the construction and effect of the Native Rights Act ...

Yet it appears that the Privy Council went even further and, suggested that questions of the existence of native title could be recognised by the Supreme Court itself prior to any determination by the Native Land Court. As Lord Davey states: ${ }^{56}$

52 See Nireaha Tamaki v Baker, above n 7; Solicitor-General v Bishop of Wellington, above n 3; Tate above $\mathrm{n}$ 7.

53 See Wi Parata v Bishop of Wellington, above n 1, 80.

54 Wi Parata $v$ Bishop of Wellington, above n 1, 80.

55 Nireaha Tamaki v Baker, above n 3, 382-83 (PC).

56 Nireaha Tamaki v Baker, above n 3, 383 (PC). 
Their Lordships think that the Supreme Court are bound to recognize the fact of the 'rightful possession and occupation of the Natives' until extinguished in accordance with law in any action in which such title is involved, and (as has been seen) means are provided for the ascertainment of such a title. The Court is not called upon in the present case to ascertain or define as against the Crown the exact nature or incidents of such a title, but merely to say whether it exists or existed as a matter of fact and whether it has been extinguished according to law. If necessary for the ascertainment of the appellant's alleged rights, the Supreme Court must seek the assistance of the Native Land Court, but that circumstance does not appear to their Lordships an objection to the Supreme Court entertaining the appellant's action.

\section{Stout CJ's Reponse}

The Privy Council's interpretation of the Native Rights Act was clearly perceived by Stout CJ as another threat to the Wi Parata precedent, and the established system of land settlement in New Zealand. In particular, Lord Davey's statement above implied that the Supreme Court could take cognizance of native title matters, in and of themselves, before the Native Land Court had converted such native title to a freehold title. Indeed, the Privy Council had concluded that the Supreme Court itself "... has jurisdiction to inquire whether as a matter of fact the land in dispute has been ceded by the Native owners to the Crown in accordance with law. ..." ${ }^{57}$ However, according to Stout CJ, the settled principle in New Zealand was the contrary one - that the Supreme Court had no such jurisdiction, and could not recognise native title claims to land, being able only to recognise the freehold certificate that the Native Land Court issued in conversion of the native title to freehold title. As Stout CJ put it: ${ }^{58}$

There has since 1865 ever been a Native Land Court to investigate Native title; and the uniform rule has been, until such investigation was determined the Supreme Court did not recognise the title of any Native to sue for possession of land uninvestigated by the [Native Land] Court. It has always been assumed - at all events up to the decision of Tamaki v Baker [1901] AC 561 - that [this] ... was a true declaration of the law. The earliest decision of the Supreme Court on the subject is, I believe, that of McIntosh [sic] v Symonds [NZ Gazette (1847), p 63]. In the very able and learned judgment of the late Mr. Justice Chapman, approved of by the Chief Justice Sir William Martin, it was held that the Supreme Court could not recognize any title not founded on the Queen's patent as the source of private title. This decision was followed in several cases, the most important of which was Wi Parata v The Bishop of Wellington ...

57 Nireaha Tamaki v Baker, above n 3, 385 (PC)

58 Hohepa Wi Neera $v$ Bishop of Wellington, above n 6, 665-66 Stout CJ. Further, Stout CJ's claim in the passage above concerning the conclusions reached in $R v$ Symonds (1847) NZPCC 387 (SC) is based on a selective reading of that judgment, and is in fact misleading. For a further discussion of this issue, see Tate, above $n 7$. 
However, in pointing in the passage above to the established New Zealand precedent that the Courts could only recognise land titles deriving from the Crown and therefore could not recognise native title, it does not appear that Stout CJ was asserting this in an attempt to overrule the Privy Council judgment. Rather, he makes this point in the context of his wider exposition of New Zealand law on native title, and points out in the passage above that it was believed to be "a true declaration of the law", "at all events up to the decision of Tamaki v Baker". In other words, far from attempting to overturn the new Privy Council judgment by asserting a contrary New Zealand one, Stout CJ was merely pointing to the extent to which the Privy Council judgment, in allowing the municipal courts to take cognisance of native title (a form of title which does not derive from the Crown) departed from established law and practice in New Zealand. ${ }^{59}$

Stout CJ also communicated what he believed was the legal uncertainty produced by the Privy Council in its Nireaha Tamaki judgment by emphasising the extent to which he believed the Privy Council's interpretation of the Native Rights Act 1865 in that judgment departed from that of all reputable legal authority in New Zealand, including those who enacted it: ${ }^{60}$

The interpretation of the Native Rights Act given by the Privy Council may have an effect not dreamed of by the Legislature that passed it, nor understood by the Judges of the Supreme Court since it was enacted.

As we saw, the Privy Council ruled in Nireaha Tamaki that the Native Rights Act bound the Crown and placed it within the jurisdiction of the Courts on native title matters when the actions of the Crown had a statutory basis. Stout CJ goes so far as to reject the Privy Council's interpretation of the Native Rights Act, and reasserts the Wi Parata view that the Crown is not bound by this statute. As he states: ${ }^{61}$

I may further point out that so far as the Native Rights Act is concerned it could not bind the Crown. Our 'Interpretation Act, 1888' is very explicit. It says that no Act must be read 'in any manner or way whatsoever to affect the rights of the Crown unless it is expressly stated therein that the Crown is bound thereby' ... I mention these facts, as they are not referred to in the judgment of Tamaki $v$ Baker, and the Privy Council does not seem to have been informed of the circumstances of the colony when - and for many years afterwards - the Act was passed.

59 Native title was the one form of land title which was held not to derive from the Crown. Rather, in so far as it was based on customary native ownership, native title was held to precede the Crown, and its acquisition of sovereignty, and to become a "burden" on the Crown's radical title once that sovereignty was acquired. See Mabo v Queensland [No. 2] (1992) 175 CLR 1, 51 Brennan J.

60 Hohepa Wi Neera $v$ Bishop of Wellington, above n 6, 667 Stout CJ.

61 Hohepa Wi Neera $v$ Bishop of Wellington, above n 6, 667 Stout CJ. For the Wi Parata view that the Crown is not bound by this statute, see Wi Parata $v$ Bishop of Wellington, above n 1, 80 Prendergast CJ. 


\section{THE COURT OF APPEAL'S BROADER STRATEGY}

So we see therefore that Stout CJ critically confronted the Privy Council's decision in Nireaha Tamaki $v$ Baker at a number of points. Yet with the exception of the last criticism above concerning the interpretation of the Native Rights Act 1865, these critical confrontations did not lead to a reassertion of the principles of Wi Parata over and above those of the Privy Council. Much of Stout CJ's argument above was a reflection on the extent to which the Privy Council in Nireaha Tamaki had departed from New Zealand precedent and the uncertainty this would produce. As such, it was not really central to the Court of Appeal in reaching its conclusions in the Hohepa Wi Neera case.

What was central was what I call the Court of Appeal's "broader strategy" in Hohepa Wi Neera. It was this strategy that allowed it to reach its final conclusions in the case, crucial to which was a ruling that, despite the wider criticisms of the Privy Council, central elements of Wi Parata could still be applied as authoritative precedent in Hohepa Wi Neera. Such a result could only be achieved by Stout CJ, and his brother judge Williams J (with one or the other of whom the rest of the Court concurred) through their adoption of a more subtle defence of Wi Parata than the articulation of its open differences from Nireaha Tamaki espoused by Stout CJ above. A deeper reading of the separate judgments of each of these figures reveals this "broader strategy" in action. Rather than confronting the Privy Council decision head-on, disputing its claims and effectively placing itself in clear opposition to the ruling of a superior court, this broader strategy attempted to minimise the impact of the Privy Council's departure from Wi Parata, either by insisting that the Privy Council's decision was not a significant departure from Wi Parata (Stout), or by insisting that the Privy Council's decision was not directly relevant to the facts of the present case (Williams).

As we have seen, the facts of the present case were almost identical to those that confronted Prendergast CJ and Richmond J in Wi Parata. ${ }^{62}$ The main difference between Prendergast CJ and Richmond J's deliberation on these facts in 1877, and the Court of Appeal's deliberation in the present case, was that the Court of Appeal was now faced with a Privy Council decision which departed significantly from the Wi Parata precedent at various points, and so mitigated against a direct application of Wi Parata to the present case. Consequently, a basic feature of the Court of Appeal's judgment in Hohepa Wi Neera was an attempt to circumvent this inconvenient

62 The basis upon which the plaintiff attempted to impeach the Crown's grant to the Bishop of New Zealand in Hohepa Wi Neera was "... that the land has never been legally ceded to the Crown, that the Crown grant of the land in 1850 to the Bishop of New Zealand ... was null and void, and that the land was still Native land, the property according to Native custom of the successors of those who were so entitled in 1848 ..." (Hohepa Wi Neera $v$ Bishop of Wellington, above $\mathrm{n}$ 6, 656. See also Hohepa Wi Neera $v$ Bishop of Wellington, above n 6, 660-61). Further, the plaintiff claimed on separate grounds that the failure to establish a school on the site as anticipated in the grant rendered the grant void and so the land in question should revert to the original native donors. (Hohepa Wi Neera v Bishop of Wellington, above n 6, 658). These were effectively the same grounds as those relied on by the plaintiff in Wi Parata $v$ Bishop of Wellington: see Wi Parata v Bishop of Wellington, above n 1, 73-76 GE Barton for the plaintiff. 
development by limiting the extent to which the Privy Council decision in Nireaha Tamaki v Baker precluded a direct application of Wi Parata to the facts of the present case. We will now consider how Stout $\mathrm{CJ}$ and Williams J each attempted this in turn.

\section{A Stout CJ's Strategy}

Although Stout CJ does not say so in so many words, it is clear that his strategy for minimising the impact of Nireaha Tamaki v Baker on the Wi Parata precedent was to minimise the extent to which the Privy Council's decision was perceived as departing from that precedent. As mentioned earlier, although the Privy Council criticised significant elements of Prendergast CJ's obiter dicta on native title in Wi Parata, and moved against the spirit of that judgment by insisting that the Crown officials dealing with native title were exercising statutory authority and so were subject to the jurisdiction of the municipal courts, it actually affirmed the conclusions Prendergast CJ arrived at in his Wi Parata judgment, in particular, his claim that a Crown grant be taken as conclusive evidence that the native title had been extinguished. ${ }^{63}$ Stout CJ therefore insisted that the present case once again involved these same legal questions, and so the conclusions of Wi Parata could once again be directly applied to it, irrespective of the Privy Council's criticism of the wider obiter dicta in that case. As Stout CJ put it: ${ }^{64}$

It does not, however, seem to me necessary to inquire how far the decision in Tamaki v Baker ... has set aside the law and procedure of the Supreme Court in dealing with the claims of Maoris to land the titles of which have not been ascertained by the Native Land Courts ... The important point in that decision bearing on this case seems to me to be that it declares that Wi Parata $v$ The Bishop of Wellington was rightly decided, though it disapproves of certain dicta in the judgment. It is affirmed [in Nireaha Tamaki $v$ Baker] that the Supreme Court has no jurisdiction to annul the grant for matters not appearing on its face, and that 'the issue of a Crown grant implies a declaration by the Crown that the Native title has been extinguished'. In my opinion, this Court should follow the decision in Wi Parata v The Bishop of Wellington ... and, following it, an answer adverse to the plaintiff ... must be entered.

Now as we have seen, in his protest the following year, Stout CJ made clear the extent to which he believed the Privy Council's decision in Nireaha Tamaki v Baker was a threat to the stability and security of land settlement in New Zealand. ${ }^{65}$ He perceived this decision to be a threat precisely because of the extent to which it departed from the Wi Parata precedent. Yet in the passage above, Stout CJ adopted the opposite tack, minimising the extent to which the Privy Council's decision

63 See Nireaha Tamaki v Baker, above n 3, 383-84 Lord Davey (PC). On Prendergast CJ's view in Wi Parata that a Crown grant is conclusive evidence that the native title has been extinguished, see Wi Parata $v$ Bishop of Wellington, above $\mathrm{n}$ 1, 78 Prendergast CJ.

64 Hohepa Wi Neera v Bishop of Wellington, above n 6, 667, Stout CJ.

65 See "Wallis and Others $v$ Solicitor General, Protest of Bench and Bar, 25 April 1903", above n 3, 746 Stout CJ. 
could be seen as a departure from Wi Parata. In so doing, he minimised the wider implications of that departure by insisting that, because the Privy Council had ruled that Wi Parata had been rightly decided on the facts, and those facts were the same in the present case, its wider criticisms of $W i$ Parata were irrelevant to the case at hand. The result was that the Privy Council's decision did not prevent the direct application of the conclusions of Wi Parata to the present case. Hence by minimising the Privy Council's departure from Wi Parata, Stout CJ was able to claim that the latter was still the authoritative precedent to be applied, at least to the facts before him.

\section{B Williams J's Strategy}

Williams J's strategy for minimising the impact of Nireaha Tamaki $v$ Baker was somewhat different to that of Stout CJ. At one level, Williams J seemed to fully accept the new legal situation on native title ushered in by the Privy Council, in particular the Privy Council's rejection of the $W i$ Parata ruling that the municipal courts had no jurisdiction over native title. He stated (without criticism) that the Privy Council's decision in Nireaha Tamaki v Baker (1901) "... decided that by virtue of 'The Native Rights Act, 1865', a suit could be brought upon a native title, and therefore that a native holding under such a title, if his title were put in jeopardy by an officer of the Crown acting outside his statutory authority, could bring a suit to restrain the officer from so acting." 66

He seemed to further affirm this new legal situation when he cited, also without criticism and therefore with apparent approval, other elements of the Nireaha Tamaki judgment that departed from the Wi Parata precedent: ${ }^{67}$

The judgment further states ... that, as at the present time the exclusive right of pre-emption by the Crown over Native lands and of extinguishing the Native title is exercised by the constitutional Ministers of the Crown, on behalf of the public, in accordance with the provisions of statutes in that behalf, the Court has jurisdiction to decide whether the provisions of those statutes have been complied with, and the Native title extinguished in accordance with them. The judgment states ... that in the case then before the Court there was no suggestion of the extinction of the appellant's title by the exercise of the prerogative outside the statutes, and questions whether such a right still exists. But the doubt as to the existence at present of a prerogative right to extinguish the Native title obviously rests on the fact that the extinguishment of Native title is stated by the Privy Council to be now regulated by statute.

Williams J does not challenge these Privy Council findings in any way, even though they clearly depart from the direction which the Court of Appeal had followed since Wi Parata, particularly concerning the extent to which the Crown is immune from native title challenge due to the existence of its prerogative. However what Williams $\mathrm{J}$ does do is to argue that none of the above Privy Council conclusions are applicable to the present case, because the facts informing the present case

66 Hohepa Wi Neera $v$ Bishop of Wellington, above n 6, 670 Williams J.

67 Hohepa Wi Neera v Bishop of Wellington, above n 6, 670 Williams J. 
occurred at a time prior to the enactment of the statutes (in particular, the Native Rights Act 1865) upon which the Privy Council relied in coming to its conclusions on native title. As Williams $\mathrm{J}$ states: 68

In the present case, however, we have to deal with transactions which took place before New Zealand became a self-governing colony, and long before the statutes now regulating the rights of Natives and the ascertainment of title to and the disposition of Native lands were in existence ... There were no statutes regulating the acquisition of Native rights of occupancy by the Crown, whether by purchase, gift from the natives, or otherwise. If the question arose in any particular case whether Native rights had been ceded to the Crown, it must have been for the Governor of the colony, the only channel through which in a Crown colony the cession could have been made, to say whether they had been ceded or not, and whether the Crown had accepted such cession. No Court would have had jurisdiction to consider the question. The Crown itself, through its Responsible Ministers in England, might have reversed the action of the Governor as a matter of administration, but not as acting judicially.

Therefore, by insisting that the Privy Council in Nireaha Tamaki v Baker had relied on statutes regulating native title which were enacted after the circumstances which gave rise to the present case, Williams $\mathrm{J}$ was able to minimise the applicability of this Privy Council decision to the facts before him. He was therefore able to follow Stout CJ in affirming the continuing relevance of $\mathrm{Wi}$ Parata to the present case: ${ }^{69}$

It is difficult to distinguish the present case from the case of Wi Parata $v$ The Bishop of Wellington, which dealt with the same subject matter. The decision in that case was approved by the Privy Council in Tamaki $v$ Baker, although certain dicta in the judgment were disapproved of ... On the authority, therefore, of Wi Parata's case, and upon general principles, I think that our judgment should be for the defendants ...

68 Hohepa Wi Neera v Bishop of Wellington, above n 6, 670-671 Williams J. In his Protest against the Privy Council, where he defends the Court of Appeal's judgment in Solicitor-General v Bishop of Wellington, above $\mathrm{n}$ 3, Williams J. follows the same strategy of rejecting the relevance of Nireaha Tamaki to the issues at hand by insisting that the statutes upon which the Privy Council relies to affirm the Courts' jurisdiction over native title arose after the relevant circumstances of the Crown's grant to the Bishop of Wellington (in other words the subject matter of the case). As Williams J states: "At the time of the transactions in question there ... were no statutes regulating the extinction of Native title. The Native Rights Act referred to in the case of Nireaha Tamaki v Baker was not passed till 1865." ("Wallis and Others v Solicitor General, Protest of Bench and Bar, 25 April 1903", above n 3, 749 Williams J).

69 Hohepa Wi Neera $v$ The Bishop of Wellington, above n 6, 671-72 Williams J. Of course, the judgment of the Court of Appeal in Solicitor-General v Bishop of Wellington, above $\mathrm{n} 3$ was not upheld on appeal. Rather, the Privy Council reversed this judgment in far more direct terms than it reversed the Court of Appeal's 1894 judgment in Nireaha Tamaki v Baker, thereby giving rise to the Court of Appeal's Protest against the Privy Council in 1903. See Wallis v Solicitor-General for New Zealand, above n 3, 187-89. 


\section{The Final Ruling in Hohepa Wi Neera}

The judgment for the defendant in Hohepa Wi Neera largely rested on the Court's response to the following questions stated for argument in the case:

1. Is the plaintiff estopped or concluded by the judgment of the Supreme Court in the case of Wi Parata

$v$ The Bishop of Wellington and Another? ${ }^{70}$

7. Is the issue of the alleged Crown grant an implied declaration by the Crown that the Native title to the land has been extinguished? ${ }^{71}$

8. Is the issue of the alleged Crown grant an implied declaration by the Crown that all the right, title, and interest of the Natives to the land is extinguished? ${ }^{72}$

Stout CJ (Edwards and Conolly JJ concurring) answered these questions in the affirmative by citing Wi Parata $v$ Bishop of Wellington as the authoritative precedent on this matter. ${ }^{73}$ Williams $\mathrm{J}$ (Denniston J concurring) agreed with Stout CJ, again citing Wi Parata as the authoritative precedent. ${ }^{74}$ The plaintiff's claim that the Crown grant could be annulled, and the land returned to the original owners, on the grounds that the pre-existing native title had not been lawfully extinguished, was therefore denied.

\section{DID NIREAHA TAMAKI MAKE A DIFFERENCE?}

Yet despite the attempts of the Court of Appeal in Hohepa Wi Neera to minimise the impact of Nireaha Tamaki on the Wi Parata precedent, did the Privy Council decision make a difference to the way in which the New Zealand Court of Appeal now approached the issue of native title? I think so. The extent of the difference can be seen in the fact that, although the facts of the case in Hohepa Wi Neera were virtually identical to those which arose in Wi Parata, the judges in Hohepa Wi Neera adjudicated on them in a very different manner to the way in which they were dealt with in that former case.

70 Hohepa Wi Neera v Bishop of Wellington, above n 6, 657.

71 Hohepa Wi Neera $v$ Bishop of Wellington, above n 6, 658 .

72 Hohepa Wi Neera $v$ Bishop of Wellington, above n 6, 658.

73 As Stout CJ put it: "[A]s I have said, the decision of the Supreme Court in Wi Parata v. The Bishop of Wellington is a decision on the main points raised in this case, and ought to be decisive of issues 6,7 , and 8." (Hohepa Wi Neera v Bishop of Wellington, above n 6, 667 Stout CJ).

74 As Williams J said: "On the authority, therefore, of Wi Parata's case, and upon general principles, I think that our judgment should be for the defendants, and that the answers to the questions stated in the case should be those suggested by His Honour." (Hohepa Wi Neera v Bishop of Wellington, above n 6, 672 Williams J). 
The very manner in which both Stout CJ and Williams J adjudicated in Hohepa Wi Neera reveals the profound difference which the Privy Council's judgment in Nireaha Tamaki v Baker had made to the New Zealand judicial environment on native title. One of the central strategies of Prendergast CJ when confronted with the same facts as the present case some twenty-five years before, was to simply deny the Court's jurisdiction over the matter, on the grounds that native title issues involving the Crown involved acts of State and so fell within the confines of the Crown prerogative. ${ }^{75}$ At one point he even admitted he was interpreting a statute to exclude the Crown precisely because any other interpretation would deny that prerogative. ${ }^{76}$ Despite facing essentially the same facts in the present case, the Court of Appeal did not resort to this strategy, even though the Court of Appeal's obiter dicta in Solicitor-General v Bishop of Wellington the previous year seemed to provide some support for doing so. ${ }^{77}$ Rather than simply accepting the Crown's declarations concerning native title as binding on the Court, as the Wi Parata precedent would require, the judges in Hohepa Wi Neera weighed the evidence for the Crown against that for the plaintiff before reaching a conclusion. ${ }^{78}$ Hohepa Wi Neera therefore showed that the Court of

75 Wi Parata v Bishop of Wellington, above n 1, 78-79.

76 As Prendergast CJ stated: "The Crown, not being named in the statute, is clearly not bound by it; as the Act, if it bound the Crown, would deprive it of a prerogative right, that namely of conclusively determining when the native title has been duly extinguished...." (Wi Parata v Bishop of Wellington, above n 1, 80).

77 In Solicitor-General v Bishop of Wellington, the Court of Appeal delivered obiter dicta on an amended statement of defence submitted by the Solicitor-General which strongly suggested that, had it been necessary to adjudicate on the issue, they would have given strong support to the principle that the Court has no jurisdiction over native title matters involving Maori tribes and the Crown. As Justice Williams put it: "The position appears to be somewhat as follows ... The Crown ... as parens patriae, is under a solemn obligation to protect the rights of Native owners of the soil. When, therefore, the Crown, as parens patriae, asserts that in that capacity it is under an obligation to Natives in respect of a property, can this Court, representing the Crown as parens patriae, say to the Crown, You shall not carry out this obligation ...? We see great difficulty in holding that, in such circumstances, the Court could or ought to interfere." (SolicitorGeneral v Bishop of Wellington, above n 3, 686 Williams J). He adds further: "[T]he Crown therefore asserts that it has duties towards the Natives who ceded the land which could not be performed if the Court administered the trust cy-près. This would place the Court in a considerable difficulty. What the original rights of the Native owners were, what the bargain was between the Natives and the Crown when the Natives ceded the land, it would be difficult, if not impossible, for this Court to inquire into, even if it were clear that it had jurisdiction to do so." (Solicitor-General v Bishop of Wellington, above n 3, 686 Williams $\mathrm{J})$.

78 Consequently, even though Williams $\mathbf{J}$ follows his line of reasoning above that in the absence of statutes regulating the extinguishment of native title, a Crown grant must be considered conclusive evidence of such extinguishment, nevertheless this is still an instance of a municipal court weighing the Crown's evidence against those of other parties (rather than denying the Court's jurisdiction in the face of declarations by the Crown). Hence Williams J's conclusion is as follows: "I think the issue of the Crown grant in 1850 is conclusive evidence that any native rights then existing in the land had been ceded to the Crown, and that the cession had been accepted by the Crown. The execution of such an instrument by the only officer who could accept a cession on behalf of the Crown necessarily implies that there has been a cession and that the Crown has accepted it." (Hohepa Wi Neera v Bishop of Wellington, above n 6, 671 Williams J). Here 
Appeal no longer automatically assumed that the Crown retained the privileged position reserved for it in Wi Parata, where its declaration alone could oust the jurisdiction of the Court and conclude all native title claims. Rather, the Court clearly claimed jurisdiction in arriving at its judgment.

In this respect, I would fundamentally disagree with Paul McHugh's analysis of the Hohepa Wi Neera judgment, where he states that "... the Court of Appeal continued the Wi Parata characterization of Crown-Maori relations on matters concerning the traditional tribal lands as 'acts of state', matters of political and moral rather than legal concern." 79 This is precisely what the Court of Appeal did not do in Hohepa Wi Neera, as any such conclusion would have forced them to refuse jurisdiction over the case, along the same lines as Prendergast CJ above. Indeed, as we shall see below, the Court of Appeal, in upholding Wi Parata in its Hohepa Wi Neera judgment, upheld it in its narrowest sense, concerning the specific questions of law decided in the case and affirmed by the Privy Council in Nireaha Tamaki v Baker. It did not uphold the wider elements of the precedent referred to by McHugh above.

So the biggest difference between Wi Parata and Hohepa Wi Neera is that the Court of Appeal accepted jurisdiction in the later case, when the Supreme Court had clearly rejected that jurisdiction, on the basis of the same facts, some twenty-five years before. Ironically therefore, even though the Court of Appeal in Hohepa Wi Neera ultimately ruled to uphold Wi Parata, it did so in terms of a process of adjudication very different from Wi Parata itself. Surely the difference can only be explained by the impact of the Privy Council's decision in Nireaha Tamaki v Baker, which had moved strongly against Wi Parata's exclusion of the jurisdiction of the municipal courts over native title.

The difference made by Nireaha Tamaki $v$ Baker is also evident in the way in which the Wi Parata precedent is affirmed in the present case. Previously, the New Zealand Courts had affirmed Wi Parata in its widest sense. ${ }^{80}$ It was on this basis that the Crown's declarations on native title were always accepted by the Courts as conclusive. Yet in Hohepa Wi Neera, the Wi Parata precedent is affirmed in its narrowest sense, in terms of the strict legal questions which it decided. ${ }^{81}$ Why? Because as both Stout CJ and Williams J state above, the Privy Council in Nireaha Tamaki v Baker affirmed Prendergast CJ's conclusions on these strict legal questions, but clearly rejected his wider

Williams J has weighed the evidence for the Crown, rather than accepting the Crown's claims at face value, as the Wi Parata precedent upholding the Crown's prerogative right would require.

79 The Maori Magna Carta, above n 10, 119.

80 For example, see Nireaha Tamaki v Baker, above n 7, 488 (CA) Richmond J. However as we have seen, subsequent judicial authority tended to ignore the terra nullius elements of Prendergast CJ's Wi Parata judgment. For one exception concerning these later authorities, see Tate, above n 7, 159-164.

81 See Hohepa Wi Neera v Bishop of Wellington, above n 6, 667 Stout CJ; 671-672 Williams J. 
obiter dicta on native title. ${ }^{82}$ Consequently, both Stout CJ and Williams J affirmed Wi Parata on the only grounds made available to them by the Privy Council. Once again, this demonstrates the profound impact which the Privy Council's decision in Nireaha Tamaki v Baker had on the deliberations of the judges in this present case, despite their attempt to minimise its difference or its relevance.

That the Court of Appeal so quickly reflected this altered landscape produced by the Privy Council's departure from Wi Parata is somewhat ironic given that the year after its Hohepa Wi Neera judgment, the Court engaged in a protest against the Privy Council whose entire sub-text was a defence of the Wi Parata precedent in its broad sense against the departures of the Privy Council in Nireaha Tamaki and Wallis $v$ Solicitor-General (1903). ${ }^{83}$ This apparent shift from their position in Hohepa Wi Neera can be partially explained by the fact that in their protest, the Court of Appeal were defending a decision - Solicitor-General v Bishop of Wellington (1901) - which was delivered prior to Hohepa Wi Neera and therefore prior to the Court of Appeal gaining access to the Privy Council's judgment in Nireaha Tamaki v Baker. Further, they were also defending this decision from a Privy Council judgment, Wallis $v$ Solicitor-General (1903), which went even further than Nireaha Tamaki $v$ Baker in its rejection of the Wi Parata precedent. ${ }^{84}$ Nevertheless, within this

82 Hohepa Wi Neera v Bishop of Wellington, above n 6, 667 Stout CJ; 671-672 Williams J. Although as we have seen, the Privy Council in Nireaha Tamaki reserved judgment on the issues of Crown prerogative arising out of the Wi Parata judgment: see Nireaha Tamaki v Baker, above n 3, 381-383; 385 Lord Davey (PC).

83 See "Wallis and Others v Solicitor General, Protest of Bench and Bar, 25 April 1903", above n 3, 730 Stout CJ; 747, 755-56 Williams J; 757 Edwards J.

84 As we have seen, the Privy Council's departure from the Wi Parata precedent in Nireaha Tamaki v Baker was qualified by the fact that it reserved judgment on the question of Crown prerogative (see Nireaha Tamaki v Baker, above n 3, 381-383; 385 Lord Davey (PC)). Hence it did not directly challenge the $W i$ Parata principle that native title matters involving Crown prerogative were outside the jurisdiction of the Courts. It was precisely this principle which the Privy Council in Wallis v Solicitor-General did challenge. As we have seen, in Solicitor-General v Bishop of Wellington, the Solicitor-General had provided an amended statement of defence in which he claimed that the terms of cession of the native land to the Crown precluded the land being administered in the ways suggested by the representatives for the Bishop of Wellington (Solicitor-General v Bishop of Wellington, above n 3, 686 Williams J). In obiter dicta, the Court of Appeal responded by implicitly upholding the Wi Parata precedent, suggesting that it didn't have the jurisdiction to question this claim by the Solicitor-General since native title matters involving the Crown were arguably matters for the Crown alone, and so outside the jurisdiction of the Courts (Solicitor-General v Bishop of Wellington, above n 3, 686 Williams J). In Wallis v Solicitor-General, the Privy Council thoroughly rejected this suggestion in the most pointed terms, suggesting that it reflected extremely badly on the independence of the Court of Appeal: "The proposition advanced on behalf of the Crown is certainly not flattering to the dignity or the independence of the highest Court in New Zealand, or even to the intelligence of the Parliament. What has the Court to do with the executive? Where there is a suit properly constituted and ripe for decision, why should justice be denied or delayed at the bidding of the executive? Why should the executive Government take upon itself to instruct the Court in the discharge of its proper functions? Surely it is for the Court, not for the executive, to determine what is a breach of trust [?]" (Wallis

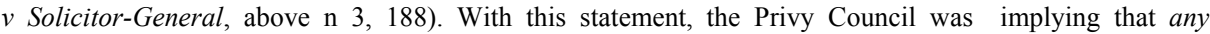


protest, the Court of Appeal's depth of commitment to Wi Parata, and its frustrations with the Privy Council's departure from it, are more than evident. ${ }^{85}$

\section{COLONIAL CONSCIOUSNESS}

We can therefore see a clear strategy at work in the judgments of Stout CJ and Williams J in Hohepa Wi Neera. Faced with a new Privy Council decision on native title which effectively overturned much of the Wi Parata precedent - a precedent which had provided the framework for New Zealand judicial reflection on native title for so long - both judges adopted strategies aimed at minimizing the relevance of this precedent to their deliberations in the present case. In so doing, they were able to retain their allegiance to Wi Parata by insisting on its continuing relevance to the facts before them.

But why would both judges go to such lengths to maintain the authority of Wi Parata in the face of Privy Council challenge? Why would they adopt strategies whose apparent purpose was to circumvent the judgment of a superior Court, at least in so far as that judgment related to the facts of the case before them? At the most immediate level, the answer lies in the material security which $W i$ Parata provided both for the Crown and for settler society in New Zealand. As we have seen, $W i$ Parata ensured that the land settlement process in New Zealand was entirely free from legal challenge by Maori tribes on the basis of native title. As we have seen, the centrality of this precedent to the stability and security of land tenure in New Zealand is demonstrated by the fact that senior New Zealand judges (including Stout CJ) insisted that any departure from it would produce instability and insecurity. ${ }^{86}$

Consequently, against this broader background, we can understand the judgments of Stout CJ and Williams $\mathrm{J}$ in Hohepa Wi Neera as informed by a desire to defend what they saw as necessary for the stability and security of land settlement in New Zealand. Such a position was clearly partial to settler over Maori interests, because this stability and security required the maintenance of a precedent which denied Maori any legal grounds for asserting native title claims against the Crown.

suggestion by the Crown that native title matters fall outside the jurisdiction of the Courts, due to the Crown prerogative powers, is not to be accepted at face-value by the Courts themselves. In other words, from the Privy Council's perspective, a mere declaration by the Crown concerning native title matters is no longer binding on the Courts, as Prendergast CJ had assumed in Wi Parata. Rather, the Privy Council implied, all matters involving native title and the Crown were now justiciable within the Courts. With this claim, a significant remnant of Wi Parata, on which the Privy Council had reserved judgment in Nireaha Tamaki v Baker, was overturned. From the Privy Council's perspective, the Crown could no longer assert prerogative powers over native title to exclude the jurisdiction of the Courts.

85 As an example of this commitment and frustration, see "Wallis and Others $v$ Solicitor-General, Protest of Bench and Bar, 25 April 1903", above n 3, 757 Edwards J.

86 See "Wallis and Others $v$ Solicitor General, Protest of Bench and Bar, 25 April 1903", above n 3, 746 Stout CJ; 757 Edwards J and Nireaha Tamaki v Baker, above n 7, 488 (CA) Richmond J; Hohepa Wi Neera v Bishop of Wellington, above n 6, 667 Stout CJ. 
It is this partiality which, I believe, reflects a "colonial consciousness" on the part of these judges. I define a "colonial consciousness" as a state of mind imbued with a fundamental commitment to settler interests within colonial society. Because colonial societies are defined, above all, by the appropriation and settlement of new land, these settler interests will be focused on land issues above all. It is the concern of these judges (at one point, as we have seen, openly articulated by Stout CJ) to maintain the stability and security of this settlement process by minimizing the extent to which it could be open to native title challenge, which most reflects this "colonial consciousness". ${ }^{87}$ The imputation of this "colonial consciousness" to the judges in Hohepa Wi Neera therefore provides us with some basis for explaining the motivation behind their deliberate attempts to circumvent and minimise the impact of the Privy Council's departure from Wi Parata, and so maintain the authority of that precedent to the facts before them in the present case.

\section{A Broader Backgrounds}

But is there any other aspect of the personal backgrounds of either Stout CJ or Williams J which would go further in explaining the presence of this "colonial consciousness", and therefore their willingness to tenaciously defend settler over Maori interests regarding native title? Sir Robert Stout had spent almost all of his adult life in New Zealand, having migrated there from the Shetland Islands in 1864 at the age of nineteen. ${ }^{88} \mathrm{He}$ spent his working life advancing through the law and politics, beginning as a representative in the Otago Provincial Council in 1872 to eventually become Attorney-General and, in 1884, Premier of New Zealand in the Stout-Vogel Ministry, before accepting the position of Chief Justice in $1899 .{ }^{89}$ Indeed, most of his education and experience had been confined to New Zealand and he thoroughly identified with its interests. ${ }^{90}$

Yet it is evident that Sir Robert identified New Zealand interests very much with settler interests. His political position, for all of his adult life, was one which divided between a liberal and a radical point of view, in the nineteenth century sense of both those terms. ${ }^{91}$ That is, he was

87 On Stout CJ's "open articulation", see "Wallis and Others $v$ Solicitor-General, Protest of Bench and Bar, 25 April 1903", above n 3, 746 Stout CJ.

88 Waldo Hilary Dunn and Ivor LM Richardson Sir Robert Stout: A Biography (AH and AW Reed, Wellington, 1961) 20-21.

89 See Dunn and Richardson, above n 88, 68, 96-97, 157-58; Cooke, above, n 4, 45.

90 As Dunn and Richardson state: "For all his adult life his home had been a small colonial outpost, cut off by its remoteness from the United Kingdom from full participation in the cross-currents of thought of contemporary Europe. Unlike several of his contemporaries at the New Zealand bar, he had enjoyed no terms at a great university or at one of the Inns of Court in London, no personal association with the outstanding leaders of the legal profession, no experience outside of the country that had been his home for more than thirty-five years." (Dunn and Richardson, above n 88,160 ).

91 Hence for much of the nineteenth century, "liberalism" was a broad church, due to the absence of any definite Labour parties on the left, and so it tended to divide between laizzez faire and progressive or even radical positions. Ironically, Stout straddled both. So for instance, he was fundamentally committed to free 
committed to a wide range of progressive causes, including development, but a development which included the interests of the broadest sections of the population..$^{92}$ In this regard, Stout CJ had a profound interest in land settlement issues, and consistently opposed the monopolization of land holdings by large private interests. ${ }^{93}$ For much of his life he advocated full state control of the land settlement process, and the leasing, rather than the selling, of land, to ensure that the state (with which he identified the general interest) received the benefit of improved land values, rather than private individuals. ${ }^{94}$ Consequently, his reformist position on land settlement was one which identified with the interests of the small settler against large private conglomerates. This did not mean he advocated the open dispossession of Maori. Indeed, he was quite critical of Crown policies regarding the public and private purchase of Maori land, as denying Maori interests, when he was involved in the Native Lands and Native Land Tenure Commission (better known as the StoutNgata Commission) in 1907 and $1908 .^{95}$ Yet regarding issues of material development, Stout CJ did

thought in religion, and yet also to the legal prohibition of alcohol (see Cooke, above n 4, 45; Dunn and Richardson, above $\mathrm{n} 88,29 ; 36 ; 57-58 ; 83 ; 86-88$ ). He was committed to progressive causes such as the extension of the franchise and triennial parliaments, and the extension of educational opportunities for the broad mass of the public, including equal educational rights for women (See Dunn and Richardson, above $\mathrm{n}$ $88,27 ; 92 ; 180 ; 184)$. Indeed, at one point, his biographers, Dunn and Richardson, even refer to Stout as the "radical of radicals", relative to others within New Zealand political life during his time as Premier (Dunn and Richardson, above n 88, 97. See also Dunn and Richardson, above n 88, 104; 121). Yet on issues of state welfare, he adopted a laizzez-faire approach: "Stout was inclined to extend the principle of individualism from the unit to the group. Each man should look out for himself and should cut his coat according to his cloth. He believed in putting a man, so far as was possible, in a position where he could keep himself. He did not, however, have faith in aids and grants for relief and he had no belief in governmental 'coddling'. Nor did he hesitate to express his views publicly. When the unemployed asked for work he told them that no government had ever stated it to be its duty to provide work, and his policy was actuated by the simple belief that the less the government interfered in people's lives and did for them the better." (Dunn and Richardson, above n 88, 108. See also Dunn and Richardson, above n 88, 119-20). However according to the authors, by the early 1890 s, Stout had qualified his anti-statist views in this respect (see Dunn and Richardson, above n 88, 145-47).

92 See Dunn and Richardson, above n 88, 26; 104.

93 See Dunn and Richardson, above n 88, 50. Dunn and Richardson state that in his native Shetlands, Sir Robert "... had abundant opportunity to observe the harshness of the land laws and, in particular, the unfortunate lot of those who occupied property at the whim of landowners ... No wonder then that he became and remained a radical land reformer and always attached such importance to the public ownership of land." (Dunn and Richardson, above n 88, 17). Indeed, these authors state that from very early in his political career, land settlement was Sir Robert's "... first consideration, land settlement before the promotion of railways or any kind of public improvements." (Dunn and Richardson, above n 88, 26). But it was land settlement within the terms of the interests of the small settler.

94 See Dunn and Richardson, above n 88, 34; 49-51; 88-89; 115.

95 See Dunn and Richardson, above n 88, 174-75; and Boast and others, above n 10, 87; and Alan Ward An Unsettled History: Treaty Claims in New Zealand Today (Bridget Williams Books, Wellington, 1999) 156. 
not see any difference between the "real" interests of Maori and those of small settlers, assuming that both would benefit from a similar model of development. ${ }^{96}$

It is in the context of his commitment to "development", albeit one tempered by a radical insistence that it be inclusive of small settler interests, that we can understand Stout CJ's concerns over native title, and in particular, his unwillingness to hold that native title was cognizable within the Courts. ${ }^{97} \mathrm{He}$ well knew that native title was a basis upon which Maori could challenge the legality of existing Crown titles, and if that were possible (as the Privy Council's judgment in Nireaha Tamaki $v$ Baker seemed to imply) then, in Stout CJ's words, "... no land title in the Colony would be safe." 98 It was not a hostility to Maori interests therefore, but rather a hostility to what threatened Stout CJ's conception of land development, which informed his "colonial consciousness" regarding native title.

Whereas Stout CJ was enrolled for a time as the first student at the University of Otago and later became a lecturer in law there, Sir Joshua Williams was a product of the English public school system and Cambridge. ${ }^{99}$ Like Stout CJ, he emigrated to New Zealand as a young man, and became very early involved in local politics, becoming a member of the Provincial Council and eventually

96 This tendency to identify Maori and settler interests can be seen in the terms of reference of the Commission, which was concerned to ".... investigate which areas of Native land were 'unoccupied or not profitably occupied' and 'how such lands can best be utilized and settled in the interests of the native owners and the public good'." (Robert Stout and Apirana Turupa Ngata "Interim Report of the Commission Appointed to Inquire into the Question of Native Lands and Native Land Tenure" [1907] III AJHR G 1, cited in Boast and Others, above $\mathrm{n} \mathrm{10,87).} \mathrm{These} \mathrm{terms} \mathrm{of} \mathrm{reference} \mathrm{themselves} \mathrm{indicate} \mathrm{the} \mathrm{extent} \mathrm{to} \mathrm{which}$ "profit" and "development" would inevitably be defined in European terms. As Dunn and Richardson state: "In many respects the most significant feature of the commission's reports was the emphasis on the importance of encouraging and training the Maoris to settle their own lands efficiently. The commission recommended that the education of Maoris should be given an agricultural bias, that model farms should be established and that the government should provide instructors to advise upon farm and stock management." (Dunn and Richardson, above n 88, 174).

97 Hence in his 1903 Protest, Stout CJ repeated his position on the exclusion of native title from the jurisdiction of the Courts (which he articulates in Hohepa Wi Neera v Bishop of Wellington, above $\mathrm{n}$ 6, 66566 Stout CJ), as follows: "The root of title being in the Crown, the Court could not recognize Native title. This has been ever held to be the law in New Zealand: see $[R v$ Symonds $]$ decided by their Honours Sir William Martin, CJ, and Mr. Justice Chapman in 1847; Wi Parata v Bishop of Wellington, decided by their Honours Sir J Prendergast and Mr Justice Richmond in 1877, and other cases. Nor did the Privy Council in Nireaha Tamaki v Baker entirely overrule this view, though it did not approve of all the dicta of the Judges in Wi Parata's case." ("Wallis and Others v Solicitor General, Protest of Bench and Bar, 25 April 1903", above n 3, 732 Stout CJ). Stout CJ's reading of $R v$ Symonds as consistent with the later judgment of $W i$ Parata is mistaken, and is based on a very selective interpretation of the earlier case. For a full discussion, see Tate, above n 7, 125-28.

98 "Wallis and Others v Solicitor General, Protest of Bench and Bar, 25 April 1903", above n 3, 746 Stout CJ.

99 See Cooke, above n 4, 53-54. On Stout CJ's educational qualifications, see Dunn and Richardson, above $\mathrm{n}$ 88 , 27-28; and Cooke, above n 4, 44-45. 
Provincial Solicitor in the Canterbury district, though never rising to the level of national politics as Stout CJ did. ${ }^{100}$ Like Stout CJ, he also took an interest in land administration, being appointed a District Land Registrar, and also Registrar General of Lands, in the Canterbury region in 1871, before being appointed a judge of the Supreme Court in 1875. ${ }^{101}$

By the time of Hohepa Wi Neera, Williams J. had thoroughly identified himself with a commitment to the Wi Parata precedent. He was a member of the Court of Appeal Bench which brought down the original Nireaha Tamaki decision in 1894, and which had upheld the Wi Parata precedent as essential to the "security of all titles in the country". ${ }^{102}$ As we have seen, it was this judgment which was subsequently overruled by the Privy Council in 1901. He also delivered the judgment of the Court of Appeal in the case of The Solicitor-General $v$ The Bishop of Wellington which, in obiter dicta, once again suggested that native title matters were entirely a matter for the prerogative of the Crown. ${ }^{103}$ Again, as we have seen, this obiter dicta was the subject of scathing criticism by the Privy Council, which in turn led to the Court of Appeal's protest in 1903. ${ }^{104}$ During the course of this Protest, Williams J. once again defended the Wi Parata precedent as the authoritative precedent on native title within New Zealand law, stating: ${ }^{105}$

It has always been held that any transactions between the Crown and the Natives relating to their title by occupancy were a matter for the Executive Government, and one into which the Court had no jurisdiction to inquire. As was laid down in Wi Parata $v$ Bishop of Wellington: 'Transactions with the Natives for the cession of their title to the Crown are to be regarded as acts of State, and therefore are not examinable in any Court' ... We considered, as every authority justified us in considering, that the root of all title was in the Crown. What the rights of any prior Native occupiers might be, or whether they had any rights, was a matter entirely for the conscience of the Crown. In any case they had no rights cognizable in this Court. Nor could this Court examine in any way what their rights were.

100 See William Downie Stewart Portrait of a Judge, Sir Joshua Strange Williams PC (Whitcome and Tombs, Wellington, 1945) 19, 20. Like Stout CJ, Sir Joshua Williams also held the position of Chancellor of a university, though in Williams' case this was the University of Otago, whereas Stout held the chancellorship of the University of New Zealand (See Stewart, 95; Dunn and Richardson, above n 88, 185).

101 See Stewart, above n 100, 20. See also Oscar Thorwald Johan Alpers Cheerful Yesterdays (Capper Press, Christchurch, 1984) 198-99; Cooke, above n 4, 54. William J's father, Joshua Williams QC, had also been involved in land law, and another Judge of the New Zealand Supreme Court, Oscar Thorwald Johan Alpers, has referred to Williams Senior's textbook on property law, Law of Real Property, as "the classical authority upon that topic" (Alpers, 198).

102 See Nireaha Tamaki v Baker, above n 7, 488 (CA) Richmond J.

103 See Solicitor-General v Bishop of Wellington, above n 3, 686 Williams J.

104 See Wallis v Solicitor-General, above n 3, 188 (PC); "Wallis and Others v Solicitor General, Protest of Bench and Bar, 25 April 1903", above n 3, 730 Stout CJ; 747, 755-56 Williams J; 757 Edwards J. .

105 "Wallis and Others v Solicitor General, Protest of Bench and Bar, 25 April 1903", above n 3, 754-55 Williams J. 
While Williams J's statement was certainly an accurate articulation of the Wi Parata precedent, his claim that "every authority" justified the Court of Appeal in holding to this precedent was in fact less than accurate. ${ }^{106}$ There were two early native title cases in New Zealand which preceded $\mathrm{Wi}$ Parata and which held, contrary to the later judgment, that native title was cognizable within municipal courts. ${ }^{107}$ Williams J's willingness to overlook these cases is similar to Stout CJ's

106 Williams $\mathrm{J}$ also made another claim in his protest concerning the unanimity of authority on native title in New Zealand when, again discussing the Court of Appeal's judgment in Solicitor-General v Bishop of Wellington, he states: "Whether, however, we were right or wrong, there was certainly an unbroken current of authority ... that the Native occupiers had no right to their land cognizable in a Court of law, and that having no such right themselves they could not transfer any right to others." ("Wallis and Others v Solicitor General, Protest of Bench and Bar, 25 April 1903", above n 3, 750,Williams J).

107 Hence as early as 1847, the New Zealand Supreme Court brought down a judgment in $R v$ Symonds, during the course of which Chapman J stated: "The intercourse of civilized nations, and especially of Great Britain, with the aboriginal Natives of America and other countries, during the last two centuries, has gradually led to the adoption and affirmation by the Colonial Courts of certain established principles of law applicable to such intercourse. Although these principles may at times have been lost sight of, yet animated by the humane spirit of modern times, our colonial Courts, and the Courts of such of the United States of America as have adopted the common law of England, have invariably affirmed and supported them; so that at this day, a line of judicial decision, the current of legal opinion, and above all, the settled practice of the colonial Governments, have concurred to clothe with certainty and precision what would otherwise have remained vague and unsettled. These principles are not the new creation or invention of the colonial Courts. They flow not from what an American writer has called the 'vice of judicial legislation'. They are in fact to be found among the earliest settled principles of our law; and they are in part deduced from those higher principles, from charters made in conformity with them, acquiesced in even down to the charter of our own Colony; and from the letter of treaties with Native tribes, wherein those principles have been asserted and acted upon." ( $R v$ Symonds, above $\mathrm{n} 58,388)$.

That native title was central to the legal principles that Chapman $\mathrm{J}$ refers to in his statement above is made clear later in his judgment when he states: "Whatever may be the opinion of jurists as to the strength or weakness of the Native title, whatsoever may have been the past vague notions of the Natives of this country, whatever may be their present clearer and still growing conception of their dominion over land, it cannot be too solemnly asserted that it is entitled to be respected, that it cannot be extinguished (at least in times of peace) otherwise than by the free consent of the Native occupiers. But for their protection, and for the sake of humanity, the Government is bound to maintain, and the Courts to assert, the Queen's exclusive right to extinguish it. It follows from what has been said, that in solemnly guaranteeing the Native title, and in securing what is called the Queen's pre-emptive right, the Treaty of Waitangi, confirmed by the Charter of the Colony, does not assert either in doctrine or in practice any thing new and unsettled." ( $R v$ Symonds, above n 58, 390).

Some twenty-five years later, Arney CJ of the Court of Appeal brought down a similar ruling on native title which equally differed from the later Wi Parata judgment. During the course of this ruling, Arney CJ said: "No doubt there is a sense in which 'Native lands' are not 'Crown lands'. The Crown is bound, both by the common law of England and by its own solemn engagements, to a full recognition of Native proprietary right. Whatever the extent of that right by established native custom appears to be, the Crown is bound to respect it." (In re 'The Lundon and Whitaker Claims Act 1871' (1872) 2 NZCA 41, 49).

In both of these judgments therefore, native title is held to be recognised by common law and so cognisable in the Courts. 
tendency to identify at least one of them as being in agreement with Wi Parata. ${ }^{108}$ In doing so, both gave a misleading impression that the authority of Wi Parata was indeed buttressed by all extant judicial authority in New Zealand. Such misrepresentation, whether intentional or not, again reflects the agonistic extent to which these judges were willing to go in defence of this precedent. ${ }^{109}$

\section{B A "Nationalist" Consciousness?}

But is it a "colonial consciousness" which best explains the Court of Appeal's tenacious commitment to Wi Parata, in the face of the Privy Council's departure from that precedent? Or is this tenacity better explained as arising from very different motives - perhaps from a nascent nationalism concerned to encourage New Zealand independence by upholding local precedents against those emanating from the Judicial Committee of the Privy Council? Certainly in the wake of the Privy Council's ruling in Wallis $v$ Solicitor General, and the official protest this engendered, Chief Justice Stout was much more willing to articulate a position critical and hostile to the Privy Council. But was it one articulated in nationalist terms - entailing the need for New Zealand autonomy and independence from that imperial body? In the context of the protest, Stout CJ certainly criticised what he saw as the Privy Council's ignorance of New Zealand law. ${ }^{110}$ It is on the basis of this alleged ignorance that Stout CJ then felt justified in questioning the continued usefulness of the Privy Council for New Zealand as follows: ${ }^{11}$

The matter is really a serious one. A great Imperial judicial tribunal sitting in the capital of the Empire, dispensing justice even to the meanest of British subjects in the uttermost parts of the earth, is a great and noble ideal. But if that tribunal is not acquainted with the laws it is called upon to interpret or administer, it may unconsciously become the worker of injustice. And if such should unfortunately happen, that Imperial spirit that is the true bond of union amongst His Majesty's subjects must be weakened. At present we in New Zealand are, so far as the Privy Council is concerned, in an unfortunate position. It has shown that it knows not our statutes, or our conveyancing terms, or our history. What the remedy may be, or can be, for such a state of things, it is not at present within my province to suggest.

We can see, therefore, that in the context of his protest, Stout CJ was quite willing to criticise what he saw as the deleterious practical effect of Privy Council appeals on New Zealand law. But

108 Hence in his Protest, Stout CJ cites $R v$ Symonds and Wi Parata as consistent, rather than contrary, precedents on native title (see "Wallis and Others $v$ Solicitor General, Protest of Bench and Bar, 25 April 1903", above n 3, 732 Stout CJ). He did the same in Hohepa Wi Neera v Bishop of Wellington, above n 6, 665-666 Stout CJ. See also Tamihana Korokai v Solicitor-General (1912) 32 NZLR 321, 344 Stout CJ.

109 I have explained in some detail elsewhere what I believe are the reasons for this consistent misreading of these early native title cases, relative to Wi Parata. See Tate, above n 7, 130-64.

110 "Wallis and Others v Solicitor General, Protest of Bench and Bar, 25 April 1903", above n 3, 732, 737, 743, 745 Stout CJ.

111 "Wallis and Others $v$ Solicitor General, Protest of Bench and Bar, 25 April 1903", above n 3, 746 Stout CJ. 
this practical effect was a product of what he perceived as Privy Council ignorance. At this point, it does not seem that he was openly articulating a position critical of the Privy Council on "nationalist" grounds, as inconsistent with New Zealand independence. However the following year, in an article in the Commonwealth Law Review, Stout CJ did precisely this. He referred to what he believed was the "anomaly" of the Australasian colonies retaining appellate appeals to the Privy Council when they had achieved self-government in the areas of legislation and administration, suggesting that such appeals were inconsistent with such self-government and the independence it implied. ${ }^{112}$ Indeed, Stout CJ goes so far as to claim that the retention of such appellate appeals is "illogical": 113

Seeing that the fullest rights of legislation and administration have been granted to the Colonies, it is illogical that the fullest rights of settling legal disputes should not also have been granted to them. Surely the making of laws, and the administering of Government affairs are as important as the interpreting of the laws we ourselves have made [?]

Stout CJ reiterated in this article the problems with the Privy Council which he referred to in his protest - not least its distance and alleged ignorance of much colonial law, and the delay and expense of appeal. ${ }^{114}$ Yet the "nationalist" dimension which he added in this article goes further

112 As Stout CJ states: "The Australasian Colonies have representative and responsible government. The Royal will in legislation ... is expressed through the different Colonial Parliaments. The Royal will in administration is expressed through the different Colonial Executives. Regarding these two functions the power and the responsibility of the Colonies are complete. ... The Colonial Legislatures are almost supreme. The only bills reserved by a Governor are those in which Imperial interests are affected. It is true the Sovereign has a veto power which may be exercised to disallow a Statute within two years of its passing, but this veto has been so rarely exercised that it is almost obsolete through non-use. The laws of a Colony can only be altered by the Legislature of that Colony. The Parliament of Britain would never attempt to interfere with the domestic legislation of a self-governing Colony. This is so taken for granted that it has passed beyond the region of discussion. In administration the same right of self-government in all Colonial concerns is so recognized that the matter is settled. No one suggests any alteration. When, however, we come to inquire what is the position regarding the Royal will in Judicature, we will find that matters are not in so satisfactory a state. These Colonies have their local tribunals from Justices of Peace Courts to Appeal Courts. There is, however, still remaining a final Court of Appeal that existed before selfgovernment was given to the Colonies. The King in his British Council - his Privy Council - hears appeals from his subjects beyond the shores of England. It is a survival of the old Colonial system. The final judicial tribunal of the Colonies is not a Colonial institution. The King, on the advice of his British Ministry, appoints the Judges that finally interpret Colonial Laws and who, in the last resort, administer justice in the Colonies. It is an anomaly in our Constitution." (Robert Stout "Appellate Tribunals for the Colonies" (September - October 1904) Commonwealth LR 3-4) ["Appellate Tribunals for the Colonies"].

113 "Appellate Tribunals for the Colonies", above n 112, 4. Perhaps with tongue somewhat in cheek, Stout CJ goes on to locate the root of this illogicality in the English character: "The English, it is said, are not, like the French, a logical people. The existence of the final Colonial Court of Appeal sitting in London, with Judges not appointed by the Colonies, is a proof of the statement." ("Appellate Tribunals for the Colonies", above $\mathrm{n} 112,4)$.

114 Hence he states: "The present system is often a denial of justice to many litigants on account of delay, cost, and the ignorance of the external Judges of what our laws have been, and are, and of want of acquaintance with our environment." ("Appellate Tribunals for the Colonies", above n 112, 13. See also "Appellate 
than the protest and, in addition to his claim above that appellate appeals to the Privy Council are inconsistent with self-government, he argues that they are also harmful to the spirit of independence which such self-government is meant to instill: ${ }^{15}$

Supposing, however, it were admitted that Appeal Court Judges in Australasia could not be expected to have the ability or learning of the members of the Judicial Committee, is that a reason for maintaining this external tribunal as an ultimate Court of Appeal? Did we ever see a child learning to walk? Its legs and arms were free, not bandaged. It was not always led. It tried, and tried again to go alone, and it had many falls before it succeeded. We cannot expect a young nation to be equal to one which has centuries of civilization behind it, and whose institutions are old and deemed sacred. But is the young nation never to go alone? Is it always to be under tutelage?

And Stout CJ concludes his article on the same note, warning: ${ }^{116}$

The psychological effect of dependence on some external power for the performance of our highest duties as citizens of these new nations should ... not be lost sight of.

So in his criticisms of the Privy Council in the Commonwealth Law Review, Stout CJ was clearly articulating a position which manifested a distinct concern with New Zealand independence, and the impact of Privy Council appeals on this. But can this same "nationalist" consciousness also explain his willingness over the previous two years to uphold the local native title precedent of $W i$ Parata in the face of Privy Council rulings departing from it? As we shall see below, there are strong grounds for holding that it cannot.

Within his protest, Williams $\mathrm{J}$ also questioned the continuing usefulness of the Privy Council for New Zealand, though again, not in terms of an explicit expression of nationalist consciousness, but

Tribunals for the Colonies", above n 112, 4-5). For a similar reference to the perceived problems of the Privy Council, concerning its knowledge of colonial laws, see Robert Stout "Is the Privy Council a Legislative Body?" (1905) 21 LQR 10 ["Is the Privy Council a Legislative Body?"].

115 "Appellate Tribunals for the Colonies", above n 112, 7.

116 "Appellate Tribunals for the Colonies", above n 112, 13. Stout CJ did not see this assertion of Australasian independence, in the form of a colonial break from the Privy Council, as inconsistent with the need for unity of Empire, much discussed at the time. This is because he did not see the Privy Council as a source of that unity. As Stout CJ put it: "The retaining of the Judicial Committee has been urged on the ground that a Court sitting in London as the ultimate Court of Appeal for the Colonies is a 'Link of Empire'. I hope never to see our Empire broken up. It is better for our race and for the world that the Empire should subsist and be powerful and strong. How can it be suggested that a Court sitting in London, determining ten, twenty or thirty cases a year for the Colonies, can keep those Colonies united to the Motherland? Is it not more likely to cause disagreements than to promote peace? If the questions that were relegated to this Central Court were Imperial, and not domestic, much might be said in defence of the argument. No one ventures to suggest that the settling of our domestic concerns in London by legislation or by administration would tend to preserve the unity of the Empire, and if not, how can it be said that the settling of some of our domestic legal matters by a Court will have that tendency?" ("Appellate Tribunals for the Colonies", above n 112, 9). 
rather in terms of his perception of the immediate failings of the Privy Council, as revealed in its criticisms of the Court of Appeal in the Wallis judgment. ${ }^{117}$ Williams $\mathrm{J}$ also followed Stout CJ in pointing to the issue of delays, and ignorance of New Zealand law, which he also believed had been displayed by the Privy Council. ${ }^{118}$ Yet in the passage below, he does in fact end with an implicit assertion of nationalist consciousness, by referring to the Privy Council judges as "strangers" and suggesting that the ultimate obligations of the judges of the Court of Appeal are to New Zealand, not the Privy Council: ${ }^{119}$

I have had the honour of being a Judge of this Court for more than twenty-eight years. I have seen Governments come and go, but never have I known any Government attempt in the slightest degree to interfere with the independence of the Court. Nor have I ever heard it suggested that this Court, in the exercise of its judicial functions, has shown a want of independence or a subservience to the Executive Government ... No suggestion of the kind has ever been made here. It has been reserved for four strangers sitting 14,000 miles away to make it. It is to our fellow-citizens in this Colony that we are responsible for our judicial conduct. If the Court retains the confidence of the people of the Colony, it is sufficient.

The echoes of the Court of Appeal's protest did indeed resonate in England, and made some impact there. ${ }^{120}$ Indeed, according to the Dictionary of New Zealand Biography, the protest initiated

117 See "Wallis and Others v Solicitor General, Protest of Bench and Bar, 25 April 1903", above n 3, 746-47, 755-56 Williams J.

118 As Williams J states: "That the decisions of this Court should continue to be subject to review by a higher Court is of the utmost importance. The knowledge that a decision can be reviewed is good alike for Judges and litigants. Whether, however, they should be reviewed by the Judicial Committee as at present constituted is a question worthy of consideration. That Court, by its imputations in the present case, by the ignorance it has shown in this and other cases of our history, of our legislation, and of our practice, and by its long-delayed judgments, has displayed every characteristic of an alien tribunal." ("Wallis and Others $v$ Solicitor General, Protest of Bench and Bar, 25 April 1903", above n 3, 756 Williams J).

119 "Wallis and Others v Solicitor General, Protest of Bench and Bar, 25 April 1903", above n 3, 755-56 Williams J. However it should be noted that, beyond the immediate issue of the Privy Council, Williams J was an Empire loyalist, at times to an almost jingoistic degree. Hence the New Zealand lawyer, William Downie Stewart, who knew Williams J personally, gives the following account of the latter's position during the Boer War, when Williams J gave a speech at a mass meeting of citizens in Dunedin. As Stewart states: "The Judge's speech is still remembered by those of my generation, because of his picture of the grave and momentous issues involved in the war - the danger to South Africa, and to our prestige in India and the Far East - and his appeal for unity. Amidst resounding cheers, he denounced those who wished to discuss the merits of the war and where the blame for it lay. 'The time for that has past', he cried. 'It may come again; it will come again, when all is over. But now if any one says to you 'But I don't approve of this war', then there is only one answer, 'Sir, you have got to approve of it. (Renewed cheering). When your mother is in trouble, it is your duty to help her, even though she may to some extent have brought the trouble on herself." (Stewart, above n 100, 82-83).

120 As William Downie Stewart has recorded: "This powerful protest made a sensation not only in New Zealand but in legal circles in England. I happened to be in London at the time and attended a Bar dinner at 
a process of agitation that eventually had a reformist outcome, when it was arranged that "... in hearing cases remitted from dominion courts the Privy Council should, if possible, have sitting with it a judge from the dominion interested." ${ }^{121}$ The result was the ironic outcome that, for all their criticisms of the Privy Council, both Stout CJ and Williams J were eventually elected to preside on this body themselves - Williams J in 1913 and Stout CJ in $1921 .^{122}$

\section{Whose Consciousness?}

Yet can the articulation of a "nationalist" consciousness in their criticisms of the Privy Council explain the effort to which these Court of Appeal judges went in defending the Wi Parata precedent? I don't think so. Firstly, much of the "nationalist" consciousness articulated above was motivated by the protest, which in turn was motivated by the statements of the Privy Council in Wallis $v$ Solicitor-General. ${ }^{123}$ Certainly the protest was as much a defence of the Wi Parata precedent as it was a protest against the injudicious use of language, and aspersions cast upon the Court of Appeal, by the Privy Council. ${ }^{124}$ But as we have seen, the Court of Appeal had shown just as much willingness to uphold Wi Parata prior to Wallis and prior to the protest. ${ }^{125}$ Indeed, the Court of Appeal's Hohepa Wi Neera judgment was delivered prior to the Privy Council's judgment in Wallis and therefore prior to the protest it engendered, so any "nationalist" spirit arising from the

which many distinguished judges were present. I sat between two KC's who questioned me about the incident, and expressed astonishment that we still acquiesced in the practice of appeals to the Privy Council." (Stewart, above n 100, 90).

121 Guy Hardy Scholefield (ed) A Dictionary of New Zealand Biography (Department of Internal Affairs, Wellington, 1940) 342 .

122 See Scholefied, above n 121, 342; 514.

123 Indeed, any "nationalist" consciousness which the protest engendered seems to be fairly derivative, and parasitical, on a prior "colonial" consciousness. In other words, it seems that it was the frustrations which their "colonial" consciousness experienced, in the face of the threats to the Wi Parata precedents, which led the Court of Appeal judges to express wider "nationalist" sentiments suggesting a need for greater independence from the Privy Council. However whether the protest engendered, or indeed reflected, a "colonial" or "nationalist" consciousness (and I suggest it reflected the former much more than the latter) it clearly did not reflect a belief on the part of New Zealand lawyers that they were "umbilically connected both historically and doctrinally to the British Constitution" as Paul McHugh has suggested - see Paul McHugh "A History of Crown Sovereignty in New Zealand" in Andrew Sharp and Paul McHugh (eds) Histories, Power and Loss. Uses of the Past - A New Zealand Commentary (Bridget Williams Books, Wellington, 2001) 197. Indeed, even the concept of a "colonial consciousness" suggests the possibility of a significant "independence" of sorts from British legal institutions and values, since as we have seen, this consciousness can give rise to interests and values very much at odds with those emanating from an imperial body like the Privy Council, and can lead in turn to demands for greater independence from these imperial bodies imposing such values.

124 See "Wallis and Others v Solicitor General, Protest of Bench and Bar, 25 April 1903", above n 3, 730 Stout CJ; 747, 755-56 Williams J; 757 Edwards J.

125 See Nireaha Tamaki v Baker, above n 7; Solicitor-General v The Bishop of Wellington, above n 7 . 
protest cannot explain the agonistic desire of the judges in Hohepa Wi Neera to defend Wi Parata. Stout CJ's later statements make it clear that he saw the Privy Council's departure from Wi Parata as a threat. ${ }^{126}$ But not a threat to the "nationalist" independence of New Zealand. Rather, a threat to the stability and security of land settlement in that country. In other words, if any "consciousness" informed the Court of Appeal's commitment to Wi Parata, and the tenacity it displayed in its defence in the wake of the Privy Council's rulings, it was a colonial and not a nationalist consciousness.

\section{The 1912 Case}

Indeed, further evidence that it was not a "nationalist" concern with New Zealand independence which informed the Court of Appeal's desire to defend local precedents on native title against the Privy Council, is provided by the Court of Appeal's later judgment on native title in the 1912 case of Tamihana Korokai $v$ Solicitor-General. ${ }^{127}$ Here, the Court of Appeal swung full circle and ultimately affirmed what had been the Privy Council's position on native title in Nireaha Tamaki and Wallis $v$ Solicitor-General - that contrary to Wi Parata, native title did fall within the jurisdiction of the Courts and the Crown could be subject to that jurisdiction. ${ }^{128}$ The Court of Appeal engaged in this about-face despite the fact that, in the wake of the Privy Council's decision in Nireaha Tamaki v Baker and Wallis v Solicitor-General, the New Zealand Parliament had passed a series of statutes expressly designed to give statutory enforcement to the Wi Parata precedent, thereby rendering the Privy Council's common law judgments to the contrary irrelevant as a determination of New Zealand law. ${ }^{129}$

126 See "Wallis and Others v Solicitor General, Protest of Bench and Bar, 25 April 1903", above n 3, 746 Stout CJ.

127 Tamihana Korokai v Solicitor-General, above n 108.

128 See Tamihana Korokai v Solicitor-General, above n 108, 345 Stout CJ; 348 Williams J; 352 Edwards J; 354 Copper J; 358 Chapman J.

129 We have seen above that, according to Paul McHugh, the New Zealand Parliament passed the Land Titles Protection Act 1902 in response to the Privy Council judgment in Nireaha Tamaki v Baker (see The Maori Magna Carta, above n 10, 118). The Land Titles Protection Act 1902 was 'consolidated' into the Land Titles Protection Act 1908, which in turn was repealed by the Native Land Act 1909 (my thanks to Alan Edwards, Law Librarian at the University of Otago, for this legislative history). Consequently, the 1909 statute was a legacy of the legislative attempts to enshrine the Wi Parata precedent in statute, thereby rendering void any Privy Council departures from that ruling. The evidence that the Native Land Act 1909 was widely perceived as reversing the Privy Council's departure from Wi Parata is provided by the Solicitor-General in the Tamihana Korokai case. In presenting the evidence for the Crown, the Solicitor-General alleged that the provisions of the Native Land Act 1909 would ensure that the decision of the Privy Council in Nireaha Tamaki $v$ Baker could no longer apply, because the relevant piece of legislation which the Privy Council had relied upon for upholding native title claims in that case (the Native Rights Act 1865) had purportedly been repealed by the Native Land Act 1909 (See Tamihana Korokai v Solicitor-General, above n 108 , 332 Solicitor-General). Indeed, he goes further and argues that the Privy Council's decision would now be "prohibited" by section 88 of the Native Land Act 1909 (Tamihana Korokai v Solicitor-General, above n 
Indeed, it was on the basis of one of these statutes (the Native Land Act 1909) that Stout CJ, in Tamihana Korokai, was able to hold that the Crown was subject to judicial determination on native title. This 1912 case involved a native title claim against the Crown to the bed of Lake Rotorua, once again raising the question of whether the municipal courts had the authority to bind the Crown over to the Native Land Court for a determination of the claim. ${ }^{130}$ Sections 84 and 85 of the Native Land Act 1909 had expressly tried to uphold the Wi Parata precedent that the Crown was not subject to the determination of the Courts on native title. Section 84 stated: ${ }^{131}$

Save so far as otherwise expressly provided in any other Act the Native customary title to land shall not be available or enforceable as against His Majesty the King by any proceedings in any Court or in any other manner.

However prior to the passing of the Native Land Act 1909, the parties to the Tamihana Korokai case had reached an agreement whereby the Solicitor-General agreed to waive "... any objection or defence which might be based on the provisions of section 84 of that Act ... except in so far as these provisions may be held to be merely declaratory of the law as existing before the passing of the said Act." ${ }^{132}$ Consequently, the 1912 native title case against the Crown was able to go ahead, despite the strictures of $\mathrm{s} 84$.

108, 332 Solicitor-General). Section 88 states, in part, "No action or other proceeding other than a proceeding by or on behalf of the Crown under the last preceding subsection shall be brought in any Court by any person for recovery of the possession of customary land. ..." (Native Land Act 19099 Edw VII 15, s 88). The Solicitor-General's evidence indicates the extent to which the Native Land Act 1909 was widely perceived, at least within government circles, as reversing the trend on native title which had been established by the Privy Council decisions in Nireaha Tamaki v Baker and Wallis v Solicitor-General, and instead re-asserting the authority of the Crown over all native title claims, as had originally been guaranteed by Prendergast CJ in Wi Parata v Bishop of Wellington.

130 See Tamihana Korokai v Solicitor-General, above n 108, 323. Indeed Stout CJ reduced the matters raised in this case to this issue alone, stating: "The point in dispute between the parties is a narrow one. The plaintiff contends that he has a statutory right to go to the Native Land Court claiming under the Native Land Act a freehold title [in return for his alleged native title]. The Solicitor-General contends that if he, as SolictorGeneral, says the land - that is, the bed of Lake Rotorua - is Crown land, that concludes the matter, and the Native Land Court cannot proceed to make any inquiries as to whether the land is Native customary land. That is the matter in contention, and it appears to me that it is the only question that this Court has at present to decide." (Tamihana Korokai v Solicitor-General, above n 108, 338 Stout CJ).

131 Native Land Act 1909, s 84.

132 Tamihana Korokai v Solicitor-General, above n 108, 326 (emphasis added). While the Solicitor-General in Tamihana Korokai agreed to waive any defence based on section 84 of the Native Land Act 1909, nevertheless in his statement to the Court, the Solicitor-General (in person) still relied on the Wi Parata precedent as the basis of the Crown's defence. He stated: "The nature of Native customary title has been considered in many cases ... and we ask the Court to confirm and ratify the principle acted on in those cases. That principle is - Native title is not available in any manner and for any purpose against the Crown. As against the Crown it is not a legal title at all." (Tamihana Korokai v Solicitor-General, above n 108, 331 Solicitor-General). The Solicitor-General then concluded by asserting the Crown's right to determine native 
Section 85 of the Native Land Act 1909 nevertheless continued in the spirit of Wi Parata by statutorily enforcing Prendergast CJ's claim that a mere declaration of the Crown concerning native title is binding on the Courts: ${ }^{133}$

A Proclamation by the Governor that any land vested in His Majesty the King is free from the Native customary title shall in all Courts and in all proceedings be accepted as conclusive proof of the fact so proclaimed.

In Tamihana Korokai, the Solicitor-General then gave evidence to the Crown upholding this principle that the declaration of the Crown was sufficient to nullify all native title claims against the Crown, stating: 134

... Native title is not available in any manner and for any purpose against the Crown. As against the Crown it is not a legal title at all. If, therefore, any dispute exists as to whether the land is native customary land or Crown land the ipse dixit of the Crown is conclusive and the question cannot be litigated in this or any other Court. This is the principle that has dominated all Native land law since the foundation of the colony: See Wi Parata v Bishop of Wellington [3 NZ Jur NS SC 72 at p. 78]; Nireaha Tamaki v Baker [12 NZ LR 483 at p. 488].

The Solicitor-General however, apparently believed that his own ipse dixit, as the Law Officer of the Crown, was sufficient to determine the matter for the Crown. In other words, it appears from the record of the case that the Solicitor-General was asserting that his declaration that the land in question was Crown land, free from native title, would (as representative of the Crown in this

title claims by mere declaration: "The conclusiveness of a claim by the Crown extends to all cases, whether the claim is based on cession, abandonment, confiscation, or any other ground, and the claim is not examinable by this Court." (Tamihana Korokai v Solicitor-General, above n 108, 334-35 Solicitor-General).

133 Native Land Act 1909, s 85. The Act therefore guaranteed the security of all Crown grants and other Crown titles from native title challenge. As section 86 states: "No Crown grant, Crown lease, or other alienation or disposition of land by the Crown, whether before or after the commencement of this Act, shall in any Court or in any proceedings be questioned or invalidated or in any manner affected by reason of the fact that the Native customary title to that land has not been duly extinguished." (Native Land Act 1909, s 86). However the Native Land Act 1909 did not nullify the legal possibility of native title itself, which would have produced a terra nullius outcome. Rather, native title was recognised within the statute. The statute simply held that native title was not effective against the Crown in any instance where the Crown decided to refuse native title claims (see s 85). This recognition of native title is evident in section 90 of the Act, which followed previous Acts in reserving to the Native Land Court the " ... exclusive jurisdiction to investigate the title to customary land, and to determine the relative interests of the owners thereof." (Native Land Act 1909, s 90).

134 Tamihana Korokai v Solicitor-General, above n 108, 331 Solicitor-General. An ipse dixit is "a dogmatic assertion made on the unsupported authority of the speaker." (Peter Edward Nygh and Peter J Butt (eds) Butterworths Australian Legal Dictionary (Butterworths, Sydney, 1997) 636). In other words, the SolicitorGeneral is claiming that the mere assertion by the Crown, as represented by the Solicitor-General in this case, ought to be sufficient to legally determine that a disputed piece of land is Crown land unencumbered by native title. 
matter) nullify the contending native title claims in this case. ${ }^{135}$ Stout CJ rejected this claim as follows: ${ }^{136}$

The Native Land Act, 1909, has various sections dealing with the customary land of the Maoris - viz., sections $84,85,86$, and 87 . What was the need of such sections if a mere declaration by a Law Officer of the Crown was all that was necessary to say that the land claimed as Native customary land was Crown land?

He continued: ${ }^{137}$

I know of no statutory authority that the Attorney-General as Attorney-General, or the Solicitor-General as Solicitor-General, has to declare that land is Crown land. The Attorney-General and the SolicitorGeneral are both high officers of State. They are legal officers, and they can appear as solicitors or counsel for the Crown, but there their functions and powers end. Their statement as to what is Crown property, unless made in accordance with some statutory power, is of no avail. If in an action they put in a plea to that effect it would have to be proved like any other pleading of a party to the action.

In coming to this conclusion, Stout CJ was following (without actually citing) the ruling of the Privy Council in Nireaha Tamaki v Baker, where Lord Davey, delivering the judgment of the Court, stated that "[i]n a constitutional country the assertion of title by the Attorney-General in a Court of Justice can be treated as pleading only and requires to be supported by evidence." 138 We can see therefore the extent to which Stout CJ's affirmation of the Privy Council view moves beyond previous New Zealand precedent on this matter. For instance, as we have seen, the Court of Appeal in 1901, in obiter dicta attached to its judgment in Solicitor-General v Bishop of Wellington, arrived at an entirely contrary opinion. On the strength of a mere suggestion by the Solicitor-General in an amended statement of defence that obligations had arisen between the Crown and a particular Maori tribe involving the cession of land, the Court suggested that such a declaration by the Crown would

135 Williams $\mathrm{J}$ asserted that the position of the Solicitor-General was as follows: "The contention of the Solicitor-General is that in all cases where land is claimed by Natives to be held by them under their customs and usages, and they seek to have their titles ascertained by the Native Land Court ... the SolicitorGeneral, by virtue of the prerogative right of the Crown, and apart from any statutory authority, could at any time step in and prevent proceedings being taken or continued." (Tamihana Korokai v Solicitor-General, above n 108, 346 Williams J. See also Tamihana Korokai v Solicitor-General, above n 108, 348-49; 351-52 Edwards J; 358 Chapman J).

136 Tamihana Korokai v Solicitor-General, above n 108, 344 Stout CJ.

137 Tamihana Korokai v Solicitor-General, above n 108, 345 Stout CJ. See also Tamihana Korokai v SolicitorGeneral, above n 108, 346 Williams J; 358 Chapman J.

138 Nireaha Tamaki v Baker, above n 3, 381. However Justice Chapman, in coming to the same conclusion in the present case, directly quotes the Privy Council's decision in Nireaha Tamaki as authority for his view: see Tamihana Korokai v Solicitor-General, above n 108, 358 Chapman J. 
be binding on the Court, leaving it no jurisdiction to interfere. ${ }^{139}$ It was this point of view which was so resoundingly rejected by the Privy Council in Wallis $v$ Solicitor-General. ${ }^{140}$ Hence we see the extent to which Stout CJ, and his concurring judges in the 1912 case, had moved to embrace the Privy Council position on native title which they had so thoroughly criticised and evaded only nine years before.

Stout CJ's rejection of the Solicitor-General's claim above meant that he was then able to uphold the plaintiff's native title claim against the Crown, despite the fact that this was clearly contrary to the intentions of the 1909 Act. In denying the authority of the Solicitor-General to determine the issue of native title merely by his own declaration, Stout CJ insisted that there were only a specified number of ways that native title claims against the Crown could be "nullified", thereby preventing any further investigation into the native title: ${ }^{141}$

There are, in my opinion, only three things that can prevent the Native Land Court entering on an inquiry as to such customary title - 1, a Proclamation of the Governor under a statute, such as has been provided in many Acts, and is so provided in section 85 of the Native Land Act, 1909; 2, a prohibition by the Governor under section 100 of the Native Land Act, 1909; 3, proof that the land has been ceded by the true owners, or that a Crown grant has been issued.

Given that none of these grounds were established by the Crown in the case, Stout CJ concluded that there was not sufficient proof to determine that the native title to the bed of Lake Rotorua, if it existed, had been extinguished. Consequently, Stout CJ ruled that the claimants had a right to take their case to the Native Land Court to determine the status of the native title against the Crown. Such a conclusion is rather ironic, given that it uses the Native Land Act 1909 to reach conclusions contrary to the intentions of the Act itself. Stout $\mathrm{CJ}$ insisted that the Act established strict procedures for the extinguishment of native title claims by the Crown, and then argued that because the Crown has not abided by these procedures in the present case, native title claims could be instituted against the Crown in the Native Land Court - the very outcome the Act was designed to avoid. Hence Stout CJ concluded as follows: ${ }^{142}$

What the customary title to the bed of Lake Rotorua may be must be considered and determined by the only Court in New Zealand that has jurisdiction to deal with Native titles - the Native Land Court ...

139 See Solicitor-General v Bishop of Wellington, above n 3, 686 Williams J.

140 See Wallis v Solicitor-General, above n 3, 187; 188 (PC).

141 Tamihana Korokai v Solicitor-General, above n 108, 345 Stout CJ. Section 100 of the Native Land Act 1909 stated: "In respect of any area of customary land the Governor may, at any time and for any reason which he thinks fit, by Order in Council prohibit the Native Land Court or the Appellate Court from proceeding to ascertain the title to that land or to make a freehold order in respect thereof; and no freehold order made in breach of any such prohibition shall be of any force or effect."

142 Tamihana Korokai v Solicitor-General, above n 108, 345-46 Stout CJ. 
[T]he plaintiff and his people have a right to go to the Native Land Court to have their title investigated, and ... the Native Land Court can only be prevented from performing its statutory duty, first, under the Native Land Act; or, second, on proof in that Court that the lands are Crown lands freed from the customary title of the Natives; or third, that there is a Crown title to the bed of the lake.

With this statement, Stout CJ was effectively recognizing the altered situation on native title produced by the Privy Council's ruling in Nireaha Tamaki v Baker that, on the basis of the Native Rights Act 1865, the New Zealand judicial authorities "... are bound to recognize the fact of the 'rightful possession and occupation of the Natives' until extinguished in accordance with law in any action in which such title is involved, and (as has been seen) means are provided for the ascertainment of such a title."143 Stout CJ still upheld the Wi Parata principle that in terms of common law, "... Native customary title was a kind of tenure that the Court could not deal with."144 Yet it was clear that he now assumed, in line with the Privy Council, that there was a statutory basis for the municipal courts, in some circumstances, to bind the Crown over to the Native Land Court and force it to submit to investigation on native title matters (albeit a statutory basis dating from 1909, not 1865). ${ }^{145}$ Once again, therefore, we see the extent to which the 1912 judgment of the Court of Appeal in Tamihana Korokai v Solicitor-General was a strong move away from the legacy of Wi Parata, and a decided step in accordance with the Privy Council. ${ }^{146}$

143 Nireaha Tamaki v Baker, above n 3, 383 (PC).

144 Tamihana Korokai v Solicitor-General, above n 108, 344 Stout CJ.

145 However we should not exaggerate the effects of this statutory recognition of native title. As we have seen, the import of the 1909 legislation was to uphold the Wi Parata precedent, and so protect the Crown from unwanted native title claims. It was only the peculiar circumstances of the case, where the Court of Appeal could find that the Crown had not abided by the lawful provisions for the extinguishment of native title, which allowed the Court of Appeal in Tamihana Korokai to bind the Crown over to the Native Land Court. In most circumstances, the 1909 legislation, and its successor statutes, would be an effective statutory bar to such an outcome. The result was that in future, native title claims in New Zealand focused on those areas which were deemed to fall outside this land legislation, such as coastal foreshores and river-beds.

146 However Paul McHugh has pointed to the highly face-saving way in which Stout CJ was able to achieve this purpose in the 1912 case. In the Nireaha Tamaki judgment, the Privy Council had relied on the Native Rights Act 1865 as the source of statutory recognition of native title. In the 1912 case on the other hand, Stout CJ had relied on the Native Land Act 1909. By focusing on an Act promulgated in 1909 as the statutory source of native title - an Act which post-dates his protest against the Privy Council in 1903 - Stout CJ was able to affirm the Privy Council ruling that there is a statutory basis for New Zealand native title, but to do so in a way that did not contradict his claims to the contrary in 1903. Paul McHugh has pointed to this face-saving manoeuvre by Stout CJ as follows: "Ignoring the possibility that earlier statutes affecting Maori traditional lands could have provided a basis for this 'statutorily recognized' title, Stout held it to have been created by the 1909 legislation. Here Stout had extricated himself, in so far as the choice of the 1909 legislation cast no shadow upon his earlier decisions." (The Maori Magna Carta, above n 10, 121). However all the other Court of Appeal judges in the 1912 case perceived the statutory basis of New Zealand native title as preceding the 1909 Act (See Tamihana Korokai v Solicitor-General, above n 108 , 347 Williams J; 351 Edwards J; 352-53 Cooper J; 355-56, 357 Chapman J). 
But what does the 1912 case tell us of the reasons behind the Court of Appeal's tenacious defence of the Wi Parata precedent a decade before? Most of all, I think, it tells us that this defence could not have been informed by a "nationalist" desire to uphold local against imperial precedents. If such a desire was behind this defence, then one must assume that this desire would be even more prevalent in 1912 than in 1902-03, because New Zealand would have had a further nine years to grow towards national maturity. And yet in 1912, the Court of Appeal moved in the opposite direction, to embrace the Privy Council precedents they had rejected a decade before. Consequently, it seems, the only consciousness which informed the Court of Appeal in its defence of Wi Parata was a "colonial" one - a desire to preserve what it thought was necessary for the stability and security of the New Zealand settlement process. Further, it appears that the anxiety and concern over this stability and security had sufficiently subsided by 1912 for the Court of Appeal to openly accept a Privy Council position which, only a decade before, they saw as a fundamental threat to this process. Consequently, far from the growth of a "nationalist" consciousness explaining this shift on native title by the Court of Appeal, between 1902 and 1912, it is best explained by a subsidence of "colonial" consciousness over this same period.

\section{CONCLUSION}

This impact of the Privy Council decisions on the deliberations of the New Zealand judges in Hohepa Wi Neera, and later in Tamihana Korokai v Solicitor-General, show the extent to which Nireaha Tamaki v Baker and Wallis $v$ Solicitor-General altered the judicial landscape on native title in New Zealand established almost a quarter of a century before by Wi Parata $v$ Bishop of Wellington. The Hohepa Wi Neera judgment revealed the extent to which the Court of Appeal judges were willing to give reign to their colonial consciousness by evading the Privy Council ruling in Nireaha Tamaki v Baker in order to uphold a cherished New Zealand precedent on native title. In contrast, the 1912 judgment of Tamihana Korokai v Solicitor-General showed the extent to which, one decade on, the Court of Appeal was capable of shedding that colonial consciousness and embracing those earlier Privy Council rulings, even at the expense of violating the legislative intentions of New Zealand Parliament, as enshrined in the Native Land Act 1909. Wi Parata was therefore a definitive judgment for the New Zealand Court of Appeal in two ways. At the turn of the century it defined that which it believed had to be defended against an imperial court, for the sake of maintaining stability and security of land settlement in New Zealand. And a decade later, it defined that which it had to leave behind if it were to shed that colonial consciousness, heal the breach with the Privy Council, and so move to a more impartial position concerning Maori and Pakeha differences over land settlement in New Zealand. 
